\title{
Review
}

\section{Melatonin for Neonatal Encephalopathy: From Bench to Bedside}

\author{
Raymand Pang ${ }^{1} \mathbb{D}$, Adnan Advic-Belltheus ${ }^{1}$, Christopher Meehan ${ }^{1}$, Daniel J. Fullen ${ }^{2}$, Xavier Golay ${ }^{3} \mathbb{D}$ and \\ Nicola J. Robertson 1,4,*
}

1 Institute for Women's Health, University College London, London WC1E 6HU, UK; r.pang@ucl.ac.uk (R.P.); a.advic-belltheus@ucl.ac.uk (A.A.-B.); chris.meehan@ucl.ac.uk (C.M.)

2 Translational Research Office, University College London, London W1T 7NF, UK; d.fullen@ucl.ac.uk

3 Department of Brain Repair and Rehabilitation, Institute of Neurology, University College London, London WC1N 3BG, UK; x.golay@ucl.ac.uk

4 Centre for Clinical Brain Sciences, University of Edinburgh, Edinburgh EH16 4SB, UK

* Correspondence: n.robertson@ucl.ac.uk

Citation: Pang, R.;

Advic-Belltheus, A.; Meehan, C.;

Fullen, D.J.; Golay, X.; Robertson, N.J.

Melatonin for Neonatal

Encephalopathy: From Bench to

Bedside. Int. J. Mol. Sci. 2021, 22, 5481.

https://doi.org/10.3390/

ijms22115481

Academic Editor: Olivier Baud

Received: 15 April 2021

Accepted: 19 May 2021

Published: 22 May 2021

Publisher's Note: MDPI stays neutral with regard to jurisdictional claims in published maps and institutional affiliations.

\section{Copyright: (c) 2021 by the authors.} Licensee MDPI, Basel, Switzerland. This article is an open access article distributed under the terms and conditions of the Creative Commons Attribution (CC BY) license (https:/ / creativecommons.org/licenses/by/ $4.0 /)$.

\begin{abstract}
Neonatal encephalopathy is a leading cause of morbidity and mortality worldwide. Although therapeutic hypothermia (HT) is now standard practice in most neonatal intensive care units in high resource settings, some infants still develop long-term adverse neurological sequelae. In low resource settings, HT may not be safe or efficacious. Therefore, additional neuroprotective interventions are urgently needed. Melatonin's diverse neuroprotective properties include antioxidant, anti-inflammatory, and anti-apoptotic effects. Its strong safety profile and compelling preclinical data suggests that melatonin is a promising agent to improve the outcomes of infants with NE. Over the past decade, the safety and efficacy of melatonin to augment HT has been studied in the neonatal piglet model of perinatal asphyxia. From this model, we have observed that the neuroprotective effects of melatonin are time-critical and dose dependent. Therapeutic melatonin levels are likely to be $15-30 \mathrm{mg} / \mathrm{L}$ and for optimal effect, these need to be achieved within the first $2-3 \mathrm{~h}$ after birth. This review summarises the neuroprotective properties of melatonin, the key findings from the piglet and other animal studies to date, and the challenges we face to translate melatonin from bench to bedside.
\end{abstract}

Keywords: neonatal encephalopathy; melatonin; neuroprotection; therapeutic hypothermia; hypoxia-ischaemia

\section{Introduction}

Intrapartum hypoxic-ischemic (HI) events, resulting in neonatal encephalopathy (NE), lead to significant neonatal mortality and morbidity worldwide. In 2010, an estimated 1.15 million babies developed NE globally, with an incidence of 8.5 per 1000 live births, and almost $45 \%$ of infants with NE either died or developed moderate-severe neurodevelopmental impairment [1]. Furthermore, over the last 20 years, the global burden of disease resulting from NE on childhood disability has increased by $35 \%$ as a result of improved survival [2].

In high resource settings, the reported incidence of brain injury, secondary to HI, is between 1.5 and 3.5 per 1000 live births [3-5]. Therapeutic hypothermia (HT), reducing the core temperature of at-risk infants to $33.5{ }^{\circ} \mathrm{C}$ for $72 \mathrm{~h}$, has become standard care for moderate-severe NE following suspected HI in high resource settings. Whilst HT is associated with a relative risk reduction of $25 \%$ in the composite outcome of death or major disability and a number needed to treat of 7-9,46\% of infants still developed adverse outcomes in clinical trials [6]. HT has expanded over the last decade to become an integral part of neonatal neurocritical care, however improvement in outcomes is modest $[7,8]$. Whilst mortality rates have reduced by more than half (10.9\% in 2014-2016) since clinical trials [9], the rate of cerebral palsy remains at $19 \%[7,8]$ and even in its absence, $34 \%$ of children still develop neurocognitive and psychological impairment that may impact school performance [10]. Diffusion-weighted magnetic resonance imaging in school-aged 
children without cerebral palsy who were cooled at birth showed widespread defects in the white matter microstructure, with disruption in brain network connectivity over regions affecting visuo-spatial processing and attention [11]. Further neuroprotective interventions are needed; in preclinical [12-14] and clinical studies [7], attempts to exploit HT effects further, by increasing the depth and duration suggest that the current protocol of $72 \mathrm{~h}$ cooling to $33.5^{\circ} \mathrm{C}$ is optimal [15]. Therefore, adjunct therapies to augment HT hold the greatest promise to improve outcomes in babies with NE.

The burden of NE secondary to intrapartum events is disproportionately higher amongst low- and middle-income countries (LMIC). In particular, sub-Saharan Africa and Southeast Asia account for more than $85 \%$ of all NE cases worldwide with regional estimates as high as 14.9 per 1000 live births [1]. Globally, over $95 \%$ of neonatal deaths and neurodevelopmental impairment occur in these regions where therapies are limited. In a retrospective cohort study in Uganda, one third of infants with NE died in the neonatal period, and of the survivors, a third developed neurodevelopmental impairment [16]. The feasibility, safety, and efficacy of HT in LMIC remains uncertain. A systematic review of seven clinical trials using various cooling devices including gel packs, water bottles, and cooled water circuits showed no treatment benefit in reducing mortality associated with NE [17]. Data for short-term and longer-term neurodevelopmental outcomes were limited. The authors were unable to conclude whether the lack of apparent treatment effects were attributed to a genuine lack of biological efficacy, related to the methodological weakness in study designs, low-level technology and core temperature instability, or suboptimal supportive care. The findings from the Hypothermia for Encephalopathy in Low and Middle-Income Countries (HELIX) study, a large multicentre, randomised controlled HT trial in south-east Asia [18] are concerning. In parallel to improving access to skilled birth attendants, good quality, timely antepartum care, and the delivery of neonatal resuscitation training programmes [19], there is an urgent unmet need to establish safe and effective therapies for babies with NE in LMIC.

Melatonin (N-acetyl-5-methoxytryptamine), an indolamine hormone has become one of the most promising neuroprotective agents for NE over the last 20 years. Its strong safety profile, ability to cross the blood brain barrier and its diverse pleiotropic properties has led to a large number of preclinical animal studies supporting its neuroprotective efficacy in reducing brain injury [20]. Whilst the preclinical data is compelling, clinical studies in infants with NE are limited [21]. Over the last decade, we have assessed the safety and therapeutic potential of melatonin to complement HT in an established, large animal piglet model of perinatal HI. The brain of the piglet, both in size and structure more closely resembles the human infant than smaller animal models [22]. The weight and size of the piglet allows standard neonatal intensive care procedures and protocols to be followed. Cerebral metabolic changes in infants can be replicated in this model [23], ensuring the translational relevance of these studies to the clinical setting. The newborn piglet model also offers the opportunity to assess in-vivo, the pharmacokinetic, physiological and systemic effects of therapeutic agents, thereby evaluating their safety, which is essential prior to clinical studies in babies.

This review summarises the main neuroprotective actions of melatonin, discusses the key findings from the University College London (UCL) neonatal piglet model of perinatal asphyxia, and explores the challenges of moving melatonin along the translational pipeline from bench to bedside to reduce the lifelong impact of NE.

\section{The Neuroprotective Action of Melatonin for Neonatal Encephalopathy}

In utero, the major source of melatonin in the developing fetus is primarily maternal. Melatonin synthesis in the pineal gland occurs in a diurnal pattern, synchronised to the light-dark cycle, reaching peak levels between 02:00 and 04:00. In response to darkness, melatonin production is triggered in the pineolycytes via a complex, autonomic neural pathway involving specialised melanopsin-containing retinal ganglion cells, the retinohypothalamic tract and the supra-chiasmatic nucleus (our biological clock) [24]. In pregnancy, 
melatonin is also synthesised at high levels by placental trophoblast cells and production gradually increases, particularly in the third trimester [25,26], to reach peak nocturnal levels at term [27]. Maternal melatonin readily crosses the placenta and likely drives the circadian melatonin levels we observe in the developing fetus [28,29]. Whilst the pineal gland develops early in embryonic life, the gland continues to grow in the first 2 years of life [30]. Following birth, the circadian rhythm of melatonin disappears and a period of transient melatonin deficiency ensues [31,32]. In neonatal rodents, melatonin declines rapidly in the first week of life [33]. The re-emergence of the circadian synthesis of melatonin in term infants is not observed until after 3 months of age [29,31]. The term newborn therefore has a period of relative melatonin deficiency; this deficiency might be a potential target for supplementary melatonin as a potent therapy for NE. Melatonin deficiency has been reported in intrauterine growth restriction [34] and prematurity [32], which are other potential patient groups where melatonin supplementation may be beneficial. Interestingly, Tauman et al. (2002) observed significantly lower levels of melatonin in the first weeks of life in infants with delayed psychomotor development [35]. In this review, we focus on melatonin as an acute therapy in the early hours and days after birth in term babies with NE.

\subsection{Evolution of Brain Injury}

The evolution of brain injury in the first hours to days following HI occurs predictably over several phases, described elegantly with phosphorus $\left({ }^{31} \mathrm{P}\right)$ and proton $\left({ }^{1} \mathrm{H}\right)$ magnetic resonance spectroscopy (MRS) in newborn infants [36-39] and piglets [40,41] (Figure 1). Two seminal studies by Lorek et al. (1994) [40] and Penrice et al. (1997) [41] reproduced the sequence of events observed in newborn infants [36,37] after birth asphyxia in newborn piglets. The acute period of $\mathrm{HI}$, termed the primary insult, is characterized by energy depletion, with a fall in [PCr]/[Pi] and [NTP]/[EPP], coinciding with a rise in Lactate to $\mathrm{N}$-acetyl aspartate (Lac/NAA) peak ratio [41]. The metabolite changes are also associated with a fall in cerebral $\mathrm{pH}$, presumed related to lactate production secondary to anaerobic metabolism [40]. Following resuscitation, a period of metabolic recovery subsequently ensues, where 31P metabolites and Lac/NAA return to baseline [40,41]. This latent phase lasts around 1-6 h (but may be longer), and is the critical window of intervention for HT. Following this period, a subsequent wave of energy failure lasting $24-48 \mathrm{~h}$ can be observed, described as secondary energy failure. On MRS, [NTP]/[EPP] falls and Lac/NAA rises despite adequate oxygenation, normal blood gas values and blood pressure [40,41]. The deterioration in cerebral energetics progresses further in some animals, as seen in newborn babies, whereas recovery was observed in some. The degree of secondary energy failure relates to the severity of energy depletion during the primary insult [40] and correlates with subsequent brain growth $[42,43]$ and neurodevelopmental outcome $[36,44]$. The tertiary phase of injury follows, spanning weeks to years after the initial insult and characterized by persisting neuroinflammation, excitotoxity, and endogenous neuro-regeneration and repair [45]. The ability to assess changes in cerebral energy metabolism using MRS and its strong association with adverse neurodevelopmental outcomes in infants has led to interest in its use as a surrogate biomarker for NE. Following recent refinement in spectral processing, ${ }^{1} \mathrm{H}$ MRS Lac/NAA peak ratio remains the most robust and accurate biomarker of early childhood outcomes in infants who are cooled [44]. Lac/NAA peak ratio is therefore one of the most important of the outcome measures in our translational model [46].

The detailed cellular and molecular mechanisms, leading to neuronal cell death and brain injury are complex and beyond the scope of this short review but are addressed by Wassink et al. (2014) [47], Gunn and Thoresen (2019) [48] and Greco et al. (2020) [49]. In this review, we will explore the key mechanisms of injury relevant to the neuroprotective action of melatonin (Figures 1 and 2). Hassell et al. (2013) [50] and Tarocco et al. (2019) [51] also provide detailed review of the role of melatonin in neuroprotection for the newborn. 


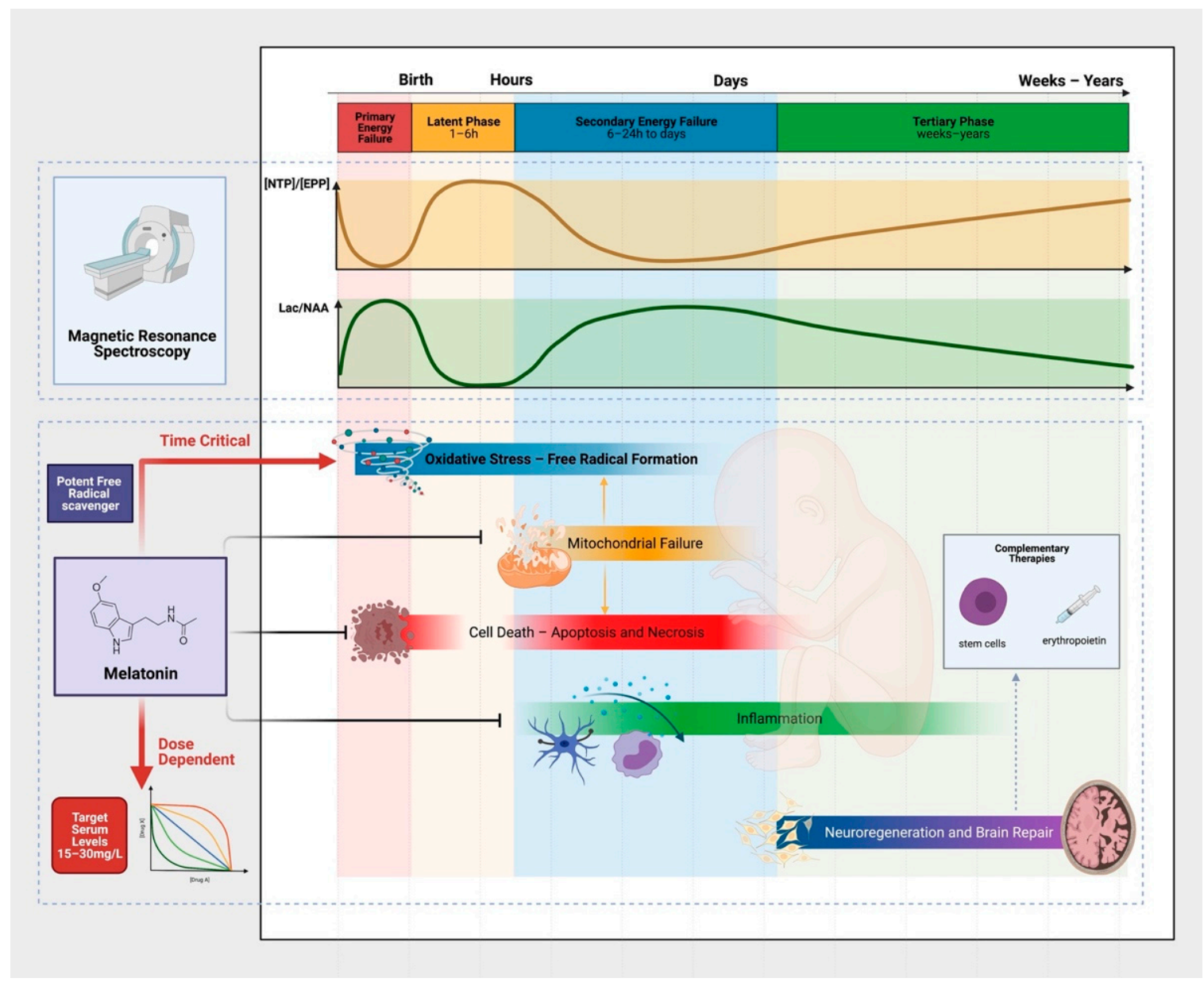

Figure 1. The Evolution of Brain Injury, Pathophysiology and the Neuroprotective Action of Melatonin. Characteristic phases (primary, latent, secondary and tertiary) of brain injury occurs following hypoxia-ischemia. These phases can be measured using proton $\left({ }^{1} \mathrm{H}\right)$ and phosphorus magnetic resonance spectroscopy. After the primary insult and a period of recovery in the latent phase, secondary energy failure occurs (characterised by a secondary rise in Lactate to $\mathrm{N}$-acetyl aspartate (Lac/NAA) peak ratio on ${ }^{1} \mathrm{H}$ MRS) in parallel with the neurotoxic cascades of cellular injury. The pathological processes are multifactorial-including oxidative stress, activation of cell death pathways, neuro-inflammation, and mitochondrial failure. The neuroprotective action of melatonin is diverse. To harness its strong antioxidant properties, supra-physiological melatonin levels (15-30 mg/L) are needed early in the neurotoxic cascade. Complementary therapies including stem cells and erythropoietin targeting the tertiary phase of injury may further improve outcomes in combination with melatonin for infants with NE.

\subsection{Oxidative Stress}

The newborn brain is particularly vulnerable to oxidative stress compared to adults [52]. Reactive oxygen species (ROS) and other free radicals are formed early following HI [53,54]. During the primary insult, metabolites required for aerobic respiration are depleted leading to reduced ATP production and the failure of the $\mathrm{Na}^{+} / \mathrm{K}^{+}$pump required to maintain the neuronal membrane resting potential and osmotic equilibrium. Membrane depolarisation leading to sodium, calcium, and water influx cause not only cytotoxic oedema, but excitotoxicity through excess release of glutamate into synaptic clefts [47]. Glutamate binds to NMDA receptors, leading to influx of $\mathrm{Ca}^{2+}$ into cells, activating nitric oxide synthase (NOS) and subsequent generation of nitric oxide $\left({ }^{\circ} \mathrm{NO}\right)$ free radicals. The mitochondria are the main source of $\mathrm{ROS}\left(\mathrm{O}_{2}{ }^{-}\right)$generated, even under normal circumstances during oxidative phosphorylation. These are cleared by antioxidant enzymes such as superoxide dismutase and glutathione peroxidase. In HI conditions and during the re-oxygenation, reperfusion phase of injury, the antioxidant system is overwhelmed, leading to a release of iron and per- 
oxide $\left({ }^{\bullet} \mathrm{OH}\right)$ ions which further contribute to oxidative damage [55]. ${ }^{\bullet} \mathrm{NO}$ diffuses readily and combines with $\mathrm{O}_{2}{ }^{\bullet-}$ to generate highly destructive peroxynitrite $\left(\mathrm{ONOO}^{-}\right)$, leading to lipid peroxidation in cell membranes, alteration of protein structure and function, and DNA damage $[47,49,55]$. The accumulation of ROS plays a central role in mitochondrial dysfunction, a hallmark in secondary energy failure [56]; oxidation of ETC complexes and cardiolipin peroxidation of the mitochondrial membrane result in uncoupling of oxidative phosphorylation, further ROS accumulation and failure to generate ATP. Ultimately, oxidative stress leads to the activation of cell death pathways, amplification of mitochondrial dysfunction and failure, further excitotoxicity, and neuro-inflammation contributing to the detrimental neurotoxic cascade [47,49,52]. Agents targeting the oxidative stress pathways, such as NOS inhibitors, have been exploited as neuroprotective interventions in animal studies of HI with variable success [57].

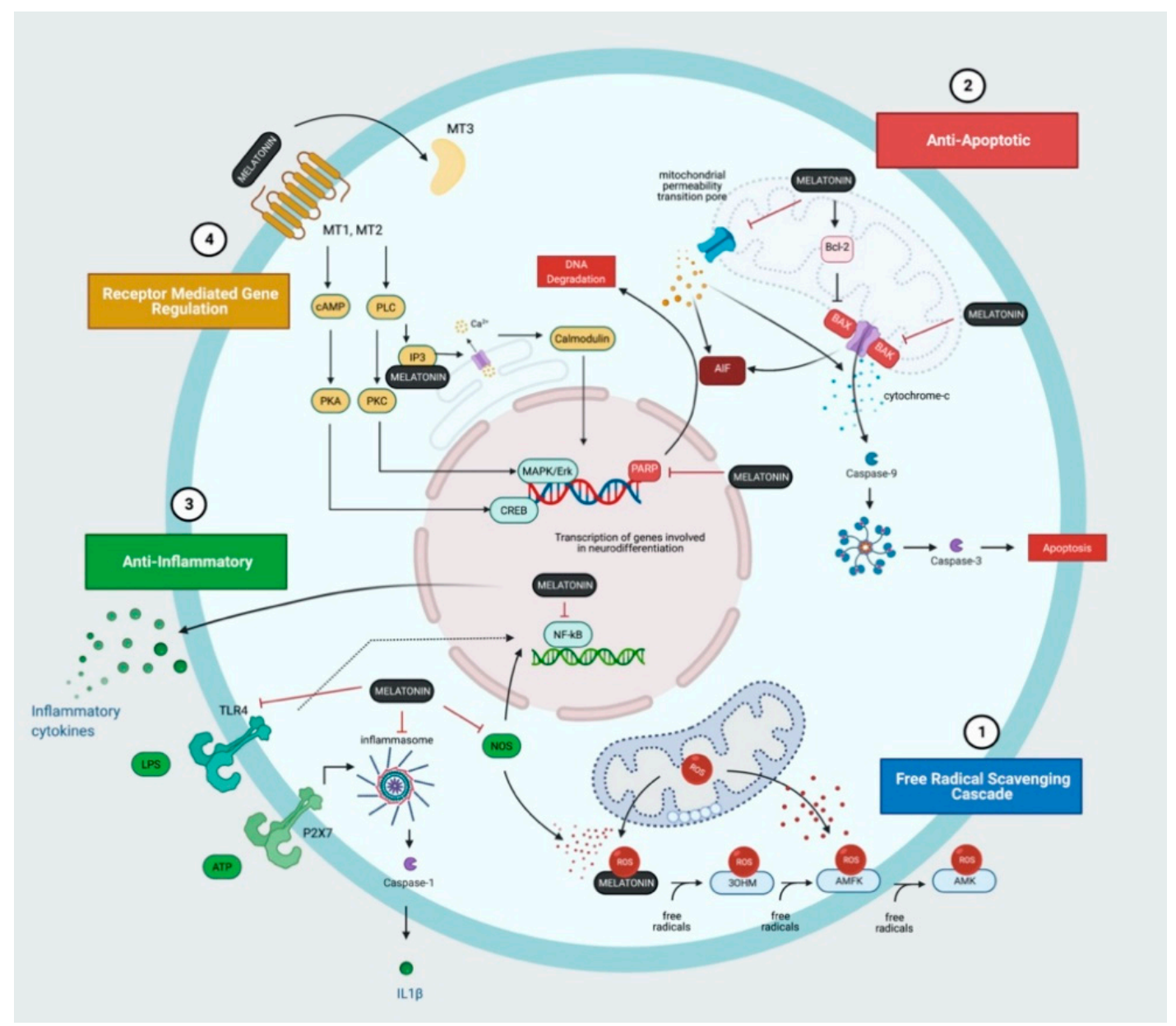

Figure 2. Melatonin and the Molecular Mechanisms of Action. (1) Melatonin and its metabolites; 3-hydroxymelatonin (3OHM), N1-acetyl-N2-formyl-5-methoxykynuramine (AFMK) and N1-acetyl-5-methoxykynuramine (AMK) form a potent free radical scavenging artillery that removes reactive oxygen species (ROS) and other free radicals produced following hypoxia-ischaemia. (2) Melatonin inhibits pro-apoptotic proteins (BAX), prevents the opening of the mitochondrial permeability transition pore and inhibits the poly(ADP-ribose) polymerase (PARP)-dependent cell death pathway. (3) Melatonin exhibits anti-inflammatory properties through the inhibition of nitrogen oxide synthase and Toll-like receptor 4 (TLR4) expression thereby suppressing inflammatory cytokine and chemokine production. (4) Melatonin also acts through receptors (MT1, MT2, MT3) to regulate a diverse range of downstream targets contributing to neuroprotection.

One of the remarkable neuroprotective actions of melatonin and its metabolites is its powerful and diverse antioxidant properties. Treatment with melatonin in animal studies have shown association with reduction in ${ }^{\circ} \mathrm{NO}$ production [58] and in lipid perox- 
idation [59-62]. In an elegant study by Miller and colleagues (2005) [54], real-time ${ }^{\bullet} \mathrm{OH}$ production was measured in the grey and white matter of fetal sheep following umbilical cord occlusion. Maternal administration of melatonin prior to $\mathrm{HI}$ ameliorated ${ }^{\bullet} \mathrm{OH}$ efflux in the grey matter during primary and secondary energy failure and was associated with a reduction in lipid peroxidation on immunohistochemistry. Melatonin acts both directly, via its non-receptor mediated action as a potent free-radical scavenger and indirectly, to regulate the antioxidant defence system, promote synthesis of antioxidant enzymes, inactivate NOS, and stabilize complex I of the ETC to reduce ROS leakage [63,64]. The concept of the melatonin free-radical scavenger cascade has been adopted to describe the highly effective sequential interaction between free radicals, melatonin, and its metabolites [64]. Each melatonin molecule has the potential to scavenge up to 10 reaction oxygen or nitrogen species [64]. Melatonin is metabolised into 3-hydroxymelatonin (3OHM), N1acetyl-N2-formyl-5-methoxykynuramine (AFMK) and N1-acetyl-5-methoxykynuramine (AMK) (Figure 2); computational modelling has shown that each have highly effective free radical scavenging capacity [65].

\subsection{Cell Death}

The mechanisms of neurodegeneration following $\mathrm{HI}$ is complex and have not been fully elucidated. Cell death likely manifests as a continuum between apoptosis and necrosis as observed in animal studies [66,67]. Our understanding of cell death has expanded beyond the traditional concepts of apoptosis, necrosis, and autophagy; the updated classification of cell death places a greater emphasis on molecular mechanisms rather than morphology [68]. Following HI, both the death-receptor mediated "extrinsic", and the cytosolic, pro-apoptotic protein mediated "intrinsic" apoptotic pathways are activated. Together, these pathways lead to the interaction between the pro-apoptotic proteins, Bax and Bak, which forms mitochondrial membrane pores, resulting in the leakage of cytochrome c into the cytosol (Figure 2). An apoptosome forms, consisting of cytochrome-c, Apaf- 1 and caspase 9, which activates caspase-3, the executioner of programmed cell death. The activation of the mitochondrial permeability transition pore (mPTP), a pathological membrane protein complex, also increases the permeability of the mitochondria in response to $\mathrm{Ca}^{2+}$ influx [69]. Melatonin's anti-apoptotic properties include activation of Bcl-2, which inhibits Bax thereby preventing membrane permeabilization [70]. Melatonin also inhibits the opening of the MPTP via receptor-dependent [71] and receptor independent mechanisms [72,73]. There is increasing evidence that sexual dimorphism exists in the mechanisms of cell death; in females, cell death occurs primarily via a caspase-3 dependent pathway whereas in males, who are more vulnerable to oxidative stress, caspase-independent, poly(ADP-ribose) polymerase (PARP)-dependent pathways predominate [74]. The versatility of melatonin also includes down-regulation of PARP protein expression [75].

\subsection{Neuro-Inflammation}

The inflammatory process following $\mathrm{HI}$ includes the release of cytokines, activation of microglia, and the recruitment of peripheral immune cells [76]. In the piglet model, cytokine (IL-1 $\alpha$, IL-6, CXCL-8, IL-10, TNF $\alpha$ ) expression was upregulated following HI, with and without prior inflammation-sensitisation [77] and serum IL-10 and IL-1 $\beta$ correlated with MRS Lac/NAA peak area ratios [78]. Clinical studies also report associations between cytokine levels in serum and CSF, severity of brain injury and neurodevelopmental outcomes in infants with NE [79-81]. In response to HI, the release of extracellular ATP, free radicals, and other damage associated molecular patterns (DAMPS) activate the Toll-like receptor (TLR) family (TLR2, 3 and 4 most widely studied), which triggers intracellular signalling pathways leading to $\mathrm{NF}_{\mathrm{k}} \mathrm{B}$ translocation and gene transcription of inflammatory cytokines and chemokines [76]. The P2X7 receptor is also activated by extracellular ATP, resulting in microglial activation, NLRP3 inflammasome formation, caspase- 1 activation and IL-1 $\beta$ release [76]. Rodent studies using agents targeting the inflammatory signalling cascade including IL-1 receptor inhibitor (IL1Ra) [82], candesartan, to reduce TLR2 ac- 
tivity [83] and TLR4 inhibitors [84] have been shown to be neuroprotective. Melatonin's neuroprotective action extends to immunomodulation; animal studies show melatonin suppresses NOS [85] and TLR4 expression [86] thereby inhibiting $\mathrm{NF}_{\mathrm{k}} \mathrm{B}$-dependent signalling. Studies also report inhibition of NLRP3 inflammasome activation [87] although the effects on neonatal $\mathrm{HI}$ models remain unknown. Whilst microglia have both pro-inflammatory and reparative roles, in vitro and rodent studies suggest melatonin improves microglial survival and attenuates the pro-inflammatory polarisation of microglia [88].

\subsection{Receptor Mediated Neuroprotection}

Rodent studies using Luzindole, an antagonist against the melatonin $G$ protein receptors MT1 and MT2, highlight a key role in the receptor-dependent action of melatonin [71] The receptor targets of melatonin are diverse but include the widely expressed MT1 and MT2 receptors, a cytosolic MT3 binding site identified as Quinolone Oxidoreductase 2 (NQO2) and the retinoid orphan receptor (ROR) family of nuclear receptors [89] (Figure 2). The distribution of MT1 and MT2 receptors in the brain [90,91] appears to be discreet and may suggest that they have divergent functions; Klosen et al. (2019) observed MT1 expression in the suprachiasmatic nucleus and pars tuberalis in the rodent brain whereas MT2 expression was more widespread (including the forebrain, hippocampus, olfactory bulb, amygdala and superior colliculus) [91]. The downstream targets remain unclear but include gene transcription of antioxidant enzymes, regulation of synaptic plasticity, neurogenesis, and regulation of cytochrome c release in mitochondria [92,93]. The development of receptor specific ligands is needed to explore the functional differences in receptors subtypes and potential mechanisms of neuroprotection. The role of $\mathrm{NQO} 2$ in neuroprotection also remains controversial. Expression in the cortex, hippocampus, and amygdala [94,95] have been reported. In an adult hamster model of neurodegeneration, NQO2 activity was associated with oxidative stress and ROS induced cell death [96]. More recently, several groups also report melatonin acts via $\alpha 7$ nicotinic acetylcholine receptors to regulate autophagy and the inflammatory response $[87,97]$.

\section{Melatonin in Combination with Therapeutic Hypothermia}

In high resource settings, HT is standard therapy for infants with moderate-severe NE secondary to $\mathrm{HI}$, therefore the assessment of neuroprotective interventions alongside $\mathrm{HT}$ is necessary for such settings. Our key findings in the evaluation of melatonin in combination with HT in the piglet model of perinatal HI are summarised in Table 1.

\subsection{Safety}

Over the last decade we have shown that melatonin infusion at rates of $5-10 \mathrm{mg} / \mathrm{kg} / \mathrm{h}$ (up to a total dose $30 \mathrm{mg} / \mathrm{kg}$ infused over $2 \mathrm{~h}$ ) is safe and not associated with hypotension in the piglet model. As melatonin is sparingly water soluble, excipients such as ethanol are commonly used in preclinical studies $[61,98,100,103]$ to obtain the desired highly concentrated melatonin solution for intravenous use.

Initial pilot studies using Sigma-Aldrich melatonin, diluted in ethanol $(2.5 \% v / v)$ given intravenously at infusion rates $\geq 10 \mathrm{mg} / \mathrm{kg} / \mathrm{h}$ was associated with hypotension requiring $0.9 \%$ saline boluses and inotropic support [98]. However, this was not observed in our most recent study using the Chiesi ethanol-free melatonin formulation given intravenously at $10 \mathrm{mg} / \mathrm{kg} / \mathrm{h} \mathrm{[101]}$. It is unclear whether ethanol contributed to the observed fall in blood pressure in the pilot studies; animal studies are conflicting. Adult ovine [104] and rodent models of sepsis $[105,106]$ report associations between high-dose $1 \mathrm{~g} / \mathrm{kg}$ ethanol administration and hypotension, mediated by the upregulation of NOS, and thereby, smooth muscle relaxation, vasodilation, and reduced cardiac output. Conversely, low dose $0.1 \mathrm{~g} / \mathrm{kg} / \mathrm{h}$ ethanol infusion, which more closely resembles ethanol concentrations in our studies $(\sim 0.1 \mathrm{~g} / \mathrm{kg} / \mathrm{h}$ ethanol for $10 \mathrm{mg} / \mathrm{kg} / \mathrm{h}$ melatonin-ethanol infusion), ameliorated septic shock in rats treated with Escherichia coli lipopolysaccharide [107]. Ethanol vehicle infusion in the piglet [100] and sheep models [103] of NE do not report significant 
blood pressure differences. However, the cardiovascular effects of ethanol require careful evaluation as following $\mathrm{HI}$, haemodynamic instability is common and cerebrovascular autoregulation is disrupted.

Table 1. Preclinical Studies Evaluating Melatonin Combined with Hypothermia for Neonatal Encephalopathy.

\begin{tabular}{|c|c|c|c|c|c|c|c|}
\hline Study & Model & $\begin{array}{c}\text { Formulation and } \\
\text { Dosing }\end{array}$ & Pharmacokinetics & aEEG & $\begin{array}{l}{ }^{1} \mathrm{H} \text { MRS } \\
\text { Lac/NAA }\end{array}$ & $\begin{array}{c}\text { Immuno- } \\
\text { Histochemistry }\end{array}$ & Other Outcomes \\
\hline $\begin{array}{l}\text { Robertson } \\
\text { et al. (2013) } \\
{[98]}\end{array}$ & $\begin{array}{l}\text { Piglet } \\
\text { model HI }\end{array}$ & $\begin{array}{l}\text { Sigma-Aldrich in } \\
\text { ethanol, } \\
30 \mathrm{mg} / \mathrm{kg} \text { over } 6 \mathrm{~h} \\
\text { at } 10 \mathrm{~min} \text { and } 24 \mathrm{~h} \\
\text { after } \mathrm{HI}\end{array}$ & $\begin{array}{l}\mathrm{Cmax} 21.0 \mathrm{mg} / \mathrm{L} \\
\text { at } 6 \mathrm{~h} \text { after } \mathrm{HI} \\
\text { Range: } \\
\text { 17-31 mg/L }\end{array}$ & No difference & $\begin{array}{l}\text { Reduction in } \\
\text { Lac/NAA in } \\
\text { thalamic voxel }\end{array}$ & $\begin{array}{l}\text { Reduction in } \\
\text { TUNEL+ cell death } \\
\text { in Hip, IC, Caud, } \\
\text { PTMN }\end{array}$ & $\begin{array}{l}\text { Reduction in gene } \\
\text { expression of CD } 86 \text { and } \\
\text { SOCS3 and increase in } \\
\text { SphK1 }\end{array}$ \\
\hline $\begin{array}{l}\text { Robertson } \\
\text { et al. (2019) } \\
\text { [99] }\end{array}$ & $\begin{array}{l}\text { Piglet } \\
\text { model HI }\end{array}$ & $\begin{array}{l}\text { Chiesi ethanol-free, } \\
5 \mathrm{mg} / \mathrm{kg} \text { over } 6 \mathrm{~h} \\
\text { at } 2 \mathrm{~h} \text { and } 26 \mathrm{~h} \text { after } \\
\mathrm{HI} \mathrm{OR} \\
15 \mathrm{mg} / \mathrm{kg} \text { over } 6 \mathrm{~h} \\
\text { at } 2 \mathrm{~h} \text { and } 26 \mathrm{~h} \text { after } \\
\mathrm{HI}\end{array}$ & $\begin{array}{l}5 \mathrm{mg} / \mathrm{kg}: \mathrm{Cmax} \\
3.97 \mathrm{mg} / \mathrm{L} \text { at } 8 \mathrm{~h} \\
\text { after HI } \\
\text { Range: } 1-5 \mathrm{mg} / \mathrm{L} \\
15 \mathrm{mg} / \mathrm{kg}: \mathrm{Cmax} \\
16.8 \mathrm{mg} / \mathrm{L} \text { at } 8 \mathrm{~h} \\
\text { after } \mathrm{HI} \\
\text { Range: } 7-19 \mathrm{mg} / \mathrm{L}\end{array}$ & No difference & No difference & $\begin{array}{l}\text { No overall } \\
\text { TUNEL+ cell death } \\
\text { reduction but } \\
\text { localised reduction } \\
\text { in sCTX }\end{array}$ & $\mathrm{N} / \mathrm{A}$ \\
\hline $\begin{array}{l}\text { Robertson } \\
\text { et al. }(2020) \\
{[100]}\end{array}$ & $\begin{array}{l}\text { Piglet } \\
\text { model HI }\end{array}$ & $\begin{array}{l}\text { Sigma-Aldrich in } \\
\text { ethanol, } 18 \mathrm{mg} / \mathrm{kg} \\
\text { over } 2 \mathrm{~h} \text { at } 1 \mathrm{~h} \text { and } \\
25 \mathrm{~h} \text { after } \mathrm{HI}\end{array}$ & $\begin{array}{l}\text { Cmax } 18.8 \mathrm{mg} / \mathrm{L} \\
\text { at } 3 \mathrm{~h} \text { after HI } \\
\text { Range: } 7-21 \mathrm{mg} / \mathrm{L}\end{array}$ & $\begin{array}{l}\text { Improved aEEG } \\
\text { from } 19-24 \mathrm{~h} \\
\text { after HI }\end{array}$ & $\begin{array}{l}\text { Reduction in } \\
\text { Lac/NAA at } \\
24 \mathrm{~h} \text { and } 48 \mathrm{~h} \\
\text { in } \mathrm{WM} \text { and } \\
\text { BGT voxels }\end{array}$ & $\begin{array}{l}\text { Reduction in } \\
\text { overall TUNEL+ } \\
\text { cell count with } \\
\text { regional reduction } \\
\text { in pvWM and IC. }\end{array}$ & $\begin{array}{l}\text { Ethanol associated with } \\
\text { partial protection: aEEG } \\
\text { recovery, reduction in } \\
\text { TUNEL+ cell count }\end{array}$ \\
\hline $\begin{array}{l}\text { Pang et al. } \\
\text { (2021) [101] }\end{array}$ & $\begin{array}{l}\text { Piglet } \\
\text { model HI }\end{array}$ & $\begin{array}{l}\text { Chiesi ethanol-free, } \\
20 \mathrm{mg} / \mathrm{kg} \text { over } 2 \mathrm{~h} \\
\text { at } 1 \mathrm{~h}, 24 \mathrm{~h} \text { and } 48 \mathrm{~h} \\
\text { after } \mathrm{HI}\end{array}$ & $\begin{array}{l}\mathrm{Cmax} 27.8 \mathrm{mg} / \mathrm{L} \\
\text { at } 3 \mathrm{~h} \text { after } \mathrm{HI} \\
\text { Range: } \\
10-30 \mathrm{mg} / \mathrm{L}\end{array}$ & $\begin{array}{l}\text { Improved aEEG } \\
\text { from } 25-30 \mathrm{~h} \\
\text { after } \mathrm{HI}\end{array}$ & $\begin{array}{l}\text { Reduction in } \\
\text { Lac/NAA at } \\
66 \mathrm{~h} \text { in BGT } \\
\text { voxel }\end{array}$ & $\begin{array}{l}\text { No overall } \\
\text { TUNEL+ cell count } \\
\text { reduction but } \\
\text { localised reduction } \\
\text { in sCTX }\end{array}$ & $\begin{array}{l}\text { Erythropoietin did not } \\
\text { provide added } \\
\text { neuroprotection to } \mathrm{HT}+ \\
\text { melatonin after } 72 \mathrm{~h}\end{array}$ \\
\hline $\begin{array}{l}\text { Carloni et al. } \\
\text { (2017) [102] }\end{array}$ & $\begin{array}{l}\text { In vitro, } \\
\text { Hip slice } \\
\text { cultures }\end{array}$ & $\begin{array}{l}\text { Sigma-Aldrich } \\
\text { dissolved in } 0.05 \% \\
\text { DMSO }\end{array}$ & $\begin{array}{l}100 \mu \mathrm{M} \\
(\sim 25 \mathrm{mg} / \mathrm{L})\end{array}$ & $\mathrm{N} / \mathrm{A}$ & $\mathrm{N} / \mathrm{A}$ & $\begin{array}{l}\text { Dose-dependent } \\
\text { reduction in cell } \\
\text { death in synergy } \\
\text { with HT }\end{array}$ & $\mathrm{N} / \mathrm{A}$ \\
\hline
\end{tabular}

aEEG: amplitude integrated electroencephalogram, Caud = caudate, Hip = Hippocampus, HI = Hypoxia-ischaemia, HT = therapeutic hypothermia, IC = internal capsule, Lac/NAA = lactate to N-acetylaspartate peak ratio, PTMN = putamen, pvWM = periventricular white matter, sCTX, sensorimotor cortex, TUNEL = Terminal deoxynucleotidyl transferase dUTP nick end labelling, SOCS3 = Suppressor of Cytokine Signaling 3, SphK1 = Sphingosine kinase 1.

Whilst chronic foetal alcohol exposure and the resultant neurological sequelae are well described [108], neonates receiving care in neonatal intensive care units are frequently exposed, acutely, to drugs containing ethanol excipients [109]. As part of our melatonin studies, we assessed the effects of ethanol excipient with and without melatonin in our piglet model of perinatal asphyxia. Surprisingly [100], we observed protection from low dose ethanol $(0.28 \mathrm{~g} / \mathrm{kg})$ itself, observed as a reduction in TUNEL+ cell death in the white matter and improved oligodendrocyte survival. The combination of melatonin with ethanol provided significant neuroprotection and augmented HT. Indeed, neuroprotective effects of ethanol have been reported in animal models of stroke [110-113]. Possible mechanisms of neuroprotection include improved cerebral glucose metabolism through the inhibition of hyperglycolysis, leading to a reduction in lactic acid accumulation and preservation of energy (ATP) production [110]. Ethanol administration is also associated with reduction in NADPH oxidase activity, resulting in reduced ROS production [110] and in apoptotic protein expression [114].

The safety profile of melatonin doses of up to $30 \mathrm{mg} / \mathrm{kg}$ in ethanol $[98,115]$ and ethanol-free formulations $[99,101]$ (Chiesi Int. pat. appl. PCT/EP2018/056423) have been reassuring in our newborn piglet studies. However, there are several factors to be considered prior to the translation to first in human trials. As no licenced intravenous formulation is available on the market to date, collaboration with pharmaceutical companies is needed to expedite drug development. Melatonin is photosensitive and degrades rapidly within hours of UV-A and UV-B exposure [116], necessitating specific storage and administration requirements. Excipient agents used to solubilise melatonin should complement the neuroprotective action of melatonin and be safe for newborn use. Close attention to the pharmacokinetic (PK) profile in babies with NE is also essential. In an open-label low dose 
melatonin PK study in preterm infants, the half-life of elimination was prolonged $(15 \mathrm{~h})$ compared to adults (45-60 $\mathrm{min}$ ) [117]. The group also noted considerable variation in drug clearance and speculated immature liver function and poor renal excretion in premature infants as contributing factors. Melatonin is metabolised by cytochrome P450 (CYP1A) enzymes in the liver and excreted in the urine. Liver and renal impairment secondary to HI may further impact melatonin elimination. Fortunately, pilot data reported that HT does not affect the PK of melatonin in term infants [118]. As discussed below, the therapeutic range of melatonin for neuroprotection from our preclinical studies is likely between 15-30 mg/L. These levels are 10,000 times higher than plasma levels in newborns at birth (typically $\sim 80 \mathrm{pg} / \mathrm{mL}$ ) [32]. The long-term consequences of supra-physiological melatonin levels remains unknown. Reassuringly, doses of up to $70 \mathrm{mg} / \mathrm{kg}$ over $24 \mathrm{~h}$ given to preterm infants for respiratory distress syndrome appeared safe in the short-term [119]. Jan et al. (2006) speculated that supplementary melatonin is unlikely to delay the onset of pineal melatonin production in infants as endogenous melatonin production is enhanced, rather than suppressed, in adults receiving melatonin therapy [120].

\subsection{Efficacy and Therapeutic Levels}

The efficacy data from four preclinical studies based on our three primary outcome measures: aEEG, ${ }^{1} \mathrm{H}$ MRS Lac/NAA and immunohistochemistry are shown in Table 1 . The pharmacokinetic profiles for these studies are shown in Figure 3.

In our first study, Robertson et al. (2013) [98], we observed significant augmentation of HT protection with Sigma-Aldrich melatonin/ethanol administered at 10mins after HI. Protection was based on improved aEEG recovery, improved thalamic cerebral energy metabolism (Lac/NAA and NTP/EPP) and reduction in TUNEL positive cells in 4 brain regions across the white and grey matter. Whilst isoprostane biomarkers were not significantly different, gene expression for immunomodulation towards a deactivated microglia phenotype (SOCS3, CD86 and SpK1) was observed. Melatonin levels of 17-31 mg/L were achieved using $30 \mathrm{mg} / \mathrm{kg}$ Sigma-Aldrich melatonin/ethanol, started at $10 \mathrm{~min}$ after HI, infused over $6 \mathrm{~h}$ and repeated at $24 \mathrm{~h}$ (Figure 3). Based on these findings and in an in vitro study [102], we estimate the therapeutic range to lie between $15-30 \mathrm{mg} / \mathrm{L}$. The widespread neuroprotection observed in this study is likely to be related to achieving therapeutic melatonin levels early on after $\mathrm{HI}$, thus utilizing the free-radical scavenging properties of melatonin.

As administration of intravenous melatonin at $10 \mathrm{~min}$ is unlikely to be possible in the clinical setting, we explored the effect of later administration. In our subsequent study, Robertson et al., 2019 [99] administered melatonin at $2 \mathrm{~h}$ after HI using a slow $6 \mathrm{~h}$ infusion, repeated at $26 \mathrm{~h}$, in conjunction with a pre-clinical dose-escalating trial using the proprietary Chiesi ethanol-free melatonin. Only partial protection was observed with the higher dose of $15 \mathrm{mg} / \mathrm{kg}$; localised reduction in TUNEL positive cells in the sensorimotor cortex was reported but $\mathrm{HT}+$ melatonin did not confer improvement in aEEG background activity or cerebral energy metabolism compared to HT alone. Whilst the absence of ethanol, shown to be partially protective in Robertson et al. (2020) [100], may have contributed to the lack of treatment benefit observed. Importantly, achievement of the Cmax $(16.8 \mathrm{mg} / \mathrm{L})$ was delayed until $\sim 8 \mathrm{~h}$ after HI (Figure 3). More rapid melatonin administration $(18 \mathrm{mg} / \mathrm{kg}$ over $2 \mathrm{~h}$ ) in the Robertson et al., 2020 [100] study, achieving target therapeutic levels $(18.84 \mathrm{mg} / \mathrm{L}$ ) earlier (within $3 \mathrm{~h}$ of $\mathrm{HI}$ ), was associated with aEEG recovery from $19 \mathrm{~h}$, reduction in Lac/NAA peak ratios in the white matter and thalamus and overall reduction in TUNEL positive cells compared to HT alone. Although the ethanol excipient likely added to the neuroprotective action of the melatonin solution in this study [100], our subsequent study (Pang et al. 2021) [101] using Chiesi melatonin at a higher dose of $20 \mathrm{mg} / \mathrm{kg}$ given over $2 \mathrm{~h}$ at $1 \mathrm{~h}$ after HI, repeated at $24 \mathrm{~h}$ and $48 \mathrm{~h}$, augmented $12 \mathrm{~h}$ HT in all three primary outcome measures. In HT + melatonin animals, cerebral background aEEG recovery was more rapid from $25-30 \mathrm{~h}$, Lac/NAA peak ratio reduced in the thalamus at $66 \mathrm{~h}$, and regional reduction in TUNEL positive cells in the sensorimotor cortex was 
observed compared to HT + vehicle. In the absence of the confounding effects of ethanol, both studies using Chiesi melatonin $[99,101]$ reported consistent localised protection in the sensorimotor cortex, a region of high metabolic activity [121] and therefore, susceptible to high levels of oxidative stress during energy failure in $\mathrm{HI}$. The $\mathrm{C}_{\max }$ achieved was higher $(27.9 \mathrm{mg} / \mathrm{L})$ and earlier (3 h) compared to the original Robertson et al., 2013 [98] study, but trough levels prior to the second dose were lower $(10 \mathrm{mg} / \mathrm{L} \mathrm{vs.} 17 \mathrm{mg} / \mathrm{L}$ ) (Figure 3). Pharmacokinetic modelling using an escalated dose of $30 \mathrm{mg} / \mathrm{kg}$ over $2 \mathrm{~h}$ may increase the area under the curve within, and maintain trough levels above, the putative $15-30 \mathrm{mg} / \mathrm{L}$ therapeutic range.

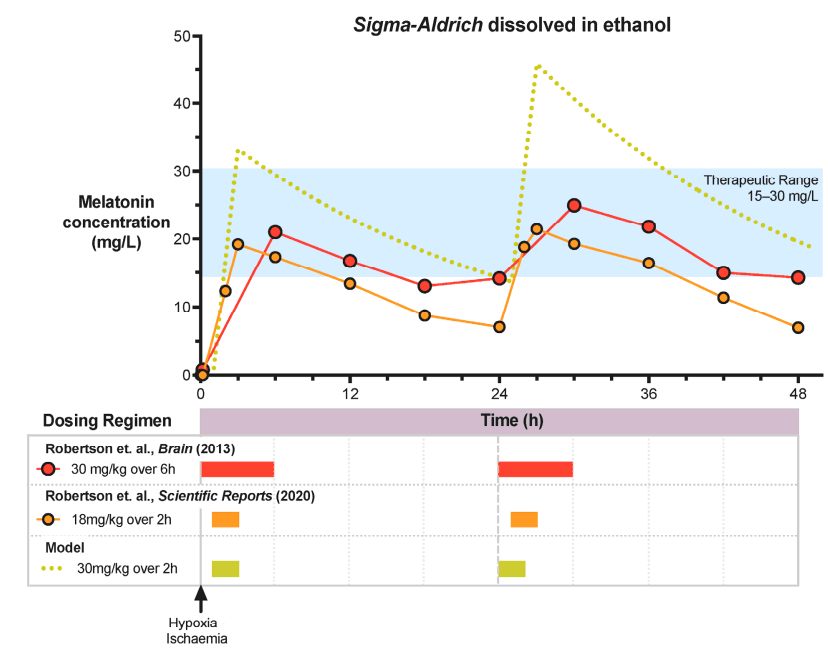

(a)

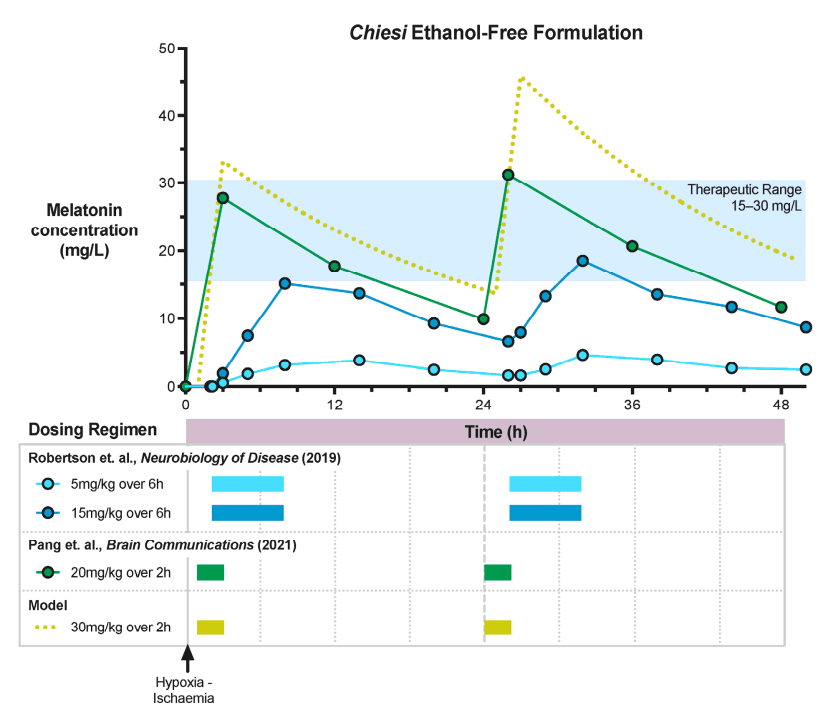

(b)

Figure 3. Pharmacokinetic Profile of Sigma-Aldrich Melatonin dissolved in ethanol (a) and Chiesi ethanol-free melatonin (b).

\subsection{Further Optimisation: Combination Therapies}

Although melatonin holds promise, our studies suggest the neuroprotective action of melatonin is dose-dependent and time-critical; putative therapeutic levels of $15-30 \mathrm{mg} / \mathrm{L}$ within $3 \mathrm{~h}$ of $\mathrm{HI}$ are required to harness its potent antioxidant properties. This is supported by the impressive attenuation of ${ }^{\bullet} \mathrm{OH}$ efflux following umbilical cord occlusion in the grey matter of foetal sheep by early pre-insult melatonin administration [54], suggesting the antioxidative effect is likely key.

Studies of other time-critical neuroprotective agents such as Xenon, although efficacious in preclinical studies [122,123], did not translate to added treatment benefit to cooling in human trials $[124,125]$, partly due to the delay of $\sim 10 \mathrm{~h}$ before treatment could be started as babies needed to be transferred to xenon centres. Melatonin is easier to administer as an intravenous drug, mitigating unnecessary delays. However, combination therapies with several neuroprotective interventions targeting the full spectrum of the neurotoxic cascade (Figure 1) may further improve outcomes.

In our most recent study (Pang et al., 2021) [101], we assessed the safety and efficacy of combination therapy using erythropoietin (Epo) in addition to HT + melatonin (triple therapy). Epo is further along the translational pipeline, undergoing phase 3 clinical trials to assess its efficacy in combination with HT in babies with moderate to severe NE [126,127]. Its diverse mechanism of action includes not only antioxidant, anti-apoptotic, and anti-inflammatory properties, which complements melatonin, but also regenerative potential targeting the tertiary phase of injury. We observed that melatonin and Epo each augmented cooling alone, however the addition of Epo to HT + melatonin did not confer added neuroprotection in the short-term after $72 \mathrm{~h}$. Unexpectedly, compared to HT + vehicle, aEEG recovery was later at 55-60 h with triple therapy and the localised reduction 
in TUNEL positive cells in the sensorimotor cortex observed with $\mathrm{HT}+$ melatonin was lost. The reason for this early negative action of Epo therapy is unclear. It is possible that delayed Epo administration may be more beneficial, and longer-term studies are needed.

There is also emerging evidence that melatonin enhances the therapeutic potential of stem cell therapies for traumatic brain injury, liver and cardiac disease, and sepsis [128]. In the piglet model of perinatal asphyxia, intranasal human mesenchymal stem cells (huMSC) augmented $12 \mathrm{~h}$ HT when targeted at the $24-48 \mathrm{~h}$ period following injury. Stem cells migrate to areas of injury and its neurotrophic response regulates cell death and neuroinflammation in the short term, and regeneration in the longer term. Interestingly, the antioxidant and anti-apoptotic properties of melatonin enhance the survival of stem cells [129]. Pre-treatment with melatonin improved the "homing ability" of stem cells to the site of injury [128]. Mesenchymal stem cells preconditioned with melatonin improved cell survival under oxidative stress and oxygen-glucose deprivation conditions in vitro [130]. In the rodent stroke model, melatonin pre-treated MSC transplantation was associated with reduction in apoptosis via an MT-receptor Erk1/2 dependent pathway [130]. The neurotrophic effects (VEGF) and neurogenesis of MSCs were enhanced with melatonin pre-treatment, resulting in improved neurobehavioral outcomes compared to animals who received untreated-MSC [130]. Studies combining the effects of early melatonin as well as "melatonin pre-treated stem cell therapies" in animal models of NE are now needed.

\section{Melatonin as a Single Agent for the Low Resource Setting}

As uncertainty remains in the safety and efficacy of HT in the low resource setting for moderate to severe NE, there is an urgent need to identify alternative, simple neuroprotective interventions. Melatonin is a promising candidate to take through the translational pipeline in such settings, given its diverse mechanisms of action and strong safety profile. Outcomes from animal studies supporting the neuroprotective effects of melatonin as a single agent for NE are compelling (Table 2). Thirteen studies [60,62,71,131-140] report improvement in histological outcomes including reduction in infarct volume, reduction in markers of apoptosis, necrosis, cell death, astrocytosis, and microgliosis. Neurobehavioral studies were also reported in 3 studies [62,132,140], observing improved cognitive performance, learning and memory, motor function, and co-ordination. Berger et al. (2019) [141] reported no overall long-term treatment effect based on brain injury volume, diffusion tensor imaging, histology and functional outcomes however the variability of injury in this model was large. Subgroup analysis revealed fewer animals with severe injury in the melatonin treated group compared to vehicle and the authors reported an absolute risk reduction for severe injury of $38.7 \%$. The authors speculated that the dosing regimen $(10 \mathrm{mg} / \mathrm{kg}$ IP given in the first day of life only; at $0 \mathrm{~h}, 6 \mathrm{~h}$, and $25 \mathrm{~h}$ after $\mathrm{HI})$ may have contributed to the lack of long-term benefit. A key limitation in the rodent studies to date is the absence of PK studies. As discussed in our piglet model, the neuroprotective effect of melatonin is likely dose dependent. The half-life of melatonin is short in rats ( $20 \mathrm{~min}$ ) and varies across animal species [142]. In the future, the inclusion of PK studies is needed to ensure optimal drug dosing and inform researchers of target therapeutic levels for future pre-clinical and human clinical trials. Care must also be taken in the choice of the excipient used to solubilise melatonin. As observed, 9 of 16 studies used $5 \%$ dimethyl sulfoxide (DMSO) (Table 2). Whilst DMSO is used in clinical practice as a cryopreservative for haematopoietic stem cell therapy [143], serious side-effects have been reported including seizures, cardiac arrest, encephalopathy, cerebral infarction, respiratory depression, severe neurotoxicity, and alternated consciousness [144]. Preclinical studies using clinically acceptable excipients for use in high-risk infants are needed.

The route of administration and dosing regimen vary across the studies. Aridas and colleagues [62] compared the efficacy of both intravenous and commercially available transdermal melatonin patches in the sheep model of perinatal asphyxia. The transdermal route is an attractive option in LMIC as patches are temperature stable; easy and quick to apply, requiring minimal training; and non-invasive, minimising infection risk. Intriguingly, 
the authors observed improved neurobehavioral outcomes in both administration routes and reduction in cleaved caspase- 3 on immunohistochemistry. Although the transdermal route shows promise, melatonin levels were 10-fold lower compared to the intravenous route and levels were not sustained. The number of animals who received transdermal melatonin were considerably smaller, and MRS outcomes were not available. A further consideration to this route of administration is the requirement of significantly higher doses to achieve the proposed $15-30 \mathrm{mg} / \mathrm{L}$ therapeutic levels. If it is feasible to develop transdermal patches to achieve such levels, the risk of local skin reactions, which is a known side-effect of transdermal melatonin may become a concern [145].

Table 2. Animal studies assessing melatonin as a single agent for neonatal encephalopathy.

\begin{tabular}{|c|c|c|c|c|}
\hline Study & Model & $\begin{array}{c}\text { Dosing and Excipient } \\
\text { (Pharmacokinetics If Available) }\end{array}$ & Outcomes & Other Remarks \\
\hline $\begin{array}{l}\text { Miller et al. } \\
\text { (2005) [54] }\end{array}$ & $\begin{array}{l}\text { Lamb model of } \\
\text { perinatal } \\
\text { asphyxia with } \\
\text { umbilical cord } \\
\text { occlusion }\end{array}$ & $\begin{array}{l}\text { Dose: } 0.5 \mathrm{mg} / \mathrm{kg} \text { bolus } 1 \mathrm{~h} \\
\text { before } \mathrm{HI}+0.5 \mathrm{mg} / \mathrm{kg} / \mathrm{h} \\
\text { infusion IV for } 2 \mathrm{~h} \\
\text { Excipient: } 1 \% \text { ethanol } \\
\text { PK: Cmax } 12,000 \mathrm{pM}(\sim 2.8 \mu \mathrm{g} / \mathrm{L}) \\
1 \mathrm{~h} \text { after administration, } 8000 \mathrm{pM} \\
(\sim 1.9 \mu \mathrm{g} / \mathrm{L}) \text { at time of } \mathrm{HI}\end{array}$ & $\begin{array}{l}\text { Biochemical: Completed } \\
\text { attenuation of OH efflux in grey } \\
\text { matter } \\
\text { Histology: Reduction in } 4 \mathrm{HNE} \\
\text { immunoreactivity in white matter } \\
\text { and grey matter regions }\end{array}$ & \\
\hline
\end{tabular}

Histology: Reduction in brain volume loss and loss of pyramidal

Carloni et al. Rice-Vannucci Dose: $15 \mathrm{mg} / \mathrm{kg} \mathrm{IP}, 5 \mathrm{~min}$ after (2008) [132] rat model $\mathrm{HI}$ repeated at 24 and $48 \mathrm{~h}$ Excipient: $5 \%$ DMSO cells in the CA1 region of the hippocampus Neurobehavioral: Reduced behavioural asymmetry, better performance in Morris maze

Biochemical: Reduction in markers of oxidative stress and nitrotyrosine expression Histology: Reduction in monocyte recruitment, microglial activation and astrocytosis

HI, single dose

Excipient: 5\% DMSO

$\begin{array}{lll}\text { Balduini et al. } & \text { Rice-Vannucci } & \text { HI, single dose } \\ \text { (2012) [60] } & \text { rat model } & \begin{array}{l}\text { Excipient: } 5 \% \text { DMSO } \\ \end{array}\end{array}$

Cetinkaya et al. (2011)[134]
Rice-Vannucci rat model
Dose: $20 \mathrm{mg} / \mathrm{kg}$ IP, given before $\mathrm{HI}$, after $\mathrm{HI}$ and $24 \mathrm{~h}$ after Excipient: 1:10 ethanol
Histology: Reduction in infarct volume, reduction in TUNEL positive cells and reduction in caspase-3
Magnesium did not provide added protection in combination with melatonin

Topiramate did not provided added protection in combination with melatonin

$\begin{array}{lll}\text { Ozyener et al. } & \text { Rice-Vannucci } & \text { Dose: } 20 \mathrm{mg} / \mathrm{kg} \mathrm{IP} \text {, given before } \\ \text { (2012) [135] } & \text { rat model } & \text { HI, after HI and } 24 \mathrm{~h} \text { after } \\ & \text { Excipient: } 1: 10 \text { ethanol }\end{array}$

Alonso-

Alconada et al. (2012) [136]

Rice-Vannucci rat model

Dose: $15 \mathrm{mg} / \mathrm{kg}$ IP, $5 \mathrm{~min}$ after $\mathrm{HI}$ repeated at 24 and $48 \mathrm{~h}$ Excipient: 5\% DMSO
Histology: Reduction in infarct volume, reduction in TUNEL positive cells in cortex and hippocampus, reduction in caspase-3
Histology: Preserved neuronal survival, reduced TUNEL, preserved brain volume, reduced white matter demyelination and reduced astrocytosis
Carloni et al.

(2014) [131]
Rice-Vannucci rat model
Dose: $15 \mathrm{mg} / \mathrm{kg}$ IP, $5 \mathrm{~min}$ after $\mathrm{HI}$ repeated at 24 and $48 \mathrm{~h}$ Excipient: 5\% DMSO
Histology: Reduction in brain injury volume in whole hemisphere, cortex and hippocampus
Melatonin reduces Endoplasmic Stress (epigenetic changes) and preserves SIRT1 expression 
Table 2. Cont.

\begin{tabular}{|c|c|c|c|c|}
\hline Study & Model & $\begin{array}{c}\text { Dosing and Excipient } \\
\text { (Pharmacokinetics If Available) }\end{array}$ & Outcomes & Other Remarks \\
\hline $\begin{array}{l}\text { Berger et al. } \\
(2016)[146]\end{array}$ & $\begin{array}{l}\text { Rice-Vannucci } \\
\text { rat model }\end{array}$ & $\begin{array}{l}\text { Dose: } 10 \mathrm{mg} / \mathrm{kg} \text { IP immediately } \\
\text { after HI, single dose } \\
\text { Excipient: } 5 \% \text { DMSO }\end{array}$ & $\begin{array}{l}\text { Biochemical: No improvement in } \\
\text { mitochondrial metabolic function } \\
\text { in neurons or astrocytes }\end{array}$ & $\begin{array}{l}\text { DMSO may } \\
\text { contribute to } \\
\text { mitochondrial } \\
\text { impairment }\end{array}$ \\
\hline $\begin{array}{l}\text { Hu et al. (2017) } \\
\text { [138] }\end{array}$ & $\begin{array}{l}\text { Rice-Vannucci } \\
\text { rat model with } \\
\text { LPS } \\
\text { sensitisation }\end{array}$ & $\begin{array}{l}\text { Dose: } 15 \mathrm{mg} / \mathrm{kg} \mathrm{IP}, 1 \mathrm{~h} \text { prior to } \\
\text { LPS, then daily for } 1 \text { week } \\
\text { Excipient: } 5 \% \text { DMSO }\end{array}$ & $\begin{array}{l}\text { Histology: melatonin improved } \\
\text { white matter recovery and } \\
\text { reduced blood brain barrier } \\
\text { permeability Reduced astrocytosis } \\
\text { and microglial activation }\end{array}$ & $\begin{array}{l}\text { Melatonin } \\
\text { suppresses TLR4 } \\
\text { NFkB } \\
\text { inflammatory } \\
\text { pathway }\end{array}$ \\
\hline $\begin{array}{l}\text { Hu et al. (2017) } \\
\text { [137] }\end{array}$ & $\begin{array}{l}\text { Rice-Vannucci } \\
\text { rat model }\end{array}$ & $\begin{array}{l}\text { Dose: } 15 \mathrm{mg} / \mathrm{kg} \mathrm{IP}, 1 \mathrm{~h} \text { prior to } \\
\text { HI injury, then daily for } 6 \text { days } \\
\text { Excipient: } 5 \% \text { DMSO }\end{array}$ & $\begin{array}{l}\text { Histology: reduced brain tissue } \\
\text { loss, inhibits neuronal apoptosis in } \\
\text { cortex }\end{array}$ & \\
\hline $\begin{array}{l}\text { Xu et al. (2017) } \\
\text { [139] }\end{array}$ & $\begin{array}{l}\text { Rice-Vannucci } \\
\text { rat model }\end{array}$ & $\begin{array}{l}\text { Dose: } 10 \mathrm{mg} / \mathrm{kg} \mathrm{IP} \text {, immediately } \\
\text { after HI, single dose } \\
\text { Excipient: Not reported }\end{array}$ & $\begin{array}{l}\text { Histology: Reduction in cerebral } \\
\text { oedema, reduction in glial cell } \\
\text { swelling and karyopyknosis and } \\
\text { interstitial tissue oedema. } \\
\text { Melatonin reduces mRNA } \\
\text { expression of oedema related } \\
\text { proteins (AQ4, ZO-1 and occludin) }\end{array}$ & \\
\hline $\begin{array}{l}\text { Carloni et al. } \\
(2017)[133]\end{array}$ & $\begin{array}{l}\text { Rice-Vannucci } \\
\text { rat model }\end{array}$ & $\begin{array}{l}\text { Dose: } 15 \mathrm{mg} / \mathrm{kg} \mathrm{IP}, 5 \mathrm{~min} \text { after } \\
\text { HI as single dose } \\
\text { Excipient: } 5 \% \text { DMSO }\end{array}$ & $\begin{array}{l}\text { Histology: Reduction in necrosis } \\
\text { and apoptosis with reduction in } \\
\text { BAX translocation and preserved } \\
\text { cytochrome c. Reduction in } \\
\text { astrocytosis }\end{array}$ & $\begin{array}{l}\text { Preserved SIRT1 } \\
\text { expression, } \\
\text { associated with } \\
\text { autophagy } \\
\text { activation }\end{array}$ \\
\hline $\begin{array}{l}\text { Sinha et al. } \\
(2018)[71]\end{array}$ & $\begin{array}{l}\text { Rice-Vannucci } \\
\text { rat model }\end{array}$ & $\begin{array}{l}\text { Dose: } 10 \mathrm{mg} / \mathrm{kg} \text { IP daily } \\
\text { Excipient: } 0.9 \% \text { saline }+3 \% \\
\text { Tween }\end{array}$ & $\begin{array}{l}\text { Histology: reduction in } \\
\text { percentage brain loss, suppresses } \\
\text { astrocytic (GFAP) and microglial } \\
\text { activation (IBA-1) }\end{array}$ & $\begin{array}{l}\text { Melatonin } \\
\text { mediates effects } \\
\text { partially through } \\
\text { MT1 receptor. } \\
\text { MT1 receptors } \\
\text { downregulated } \\
\text { following HI, } \\
\text { upregulated with } \\
\text { melatonin }\end{array}$ \\
\hline
\end{tabular}

\section{(6) Intravenous}

Dose: $\sim 15 \mathrm{mg} / \mathrm{kg}$ IV, started at $30 \mathrm{~min}$, given as 2 hourly $5 \mathrm{mg}$ boluses over $24 \mathrm{~h}$

Excipient: absolute ethanol $2 \mathrm{~mL}$ Lamb model of $\quad 0.9 \%$ saline containing 3\% Tween

Aridas et. Al. perinatal (2018) [62] asphyxia with umbilical cord occlusion

\section{(2) Transdermal patches}

Dose $6 \times 5 \mathrm{mg}$ patches (total 30 $\mathrm{mg}$ ) applied at $30 \mathrm{~min}$, replaced at $12 \mathrm{~h}$

PK: Intravenous: Cmax 150 $\mathrm{ng} / \mathrm{mL}(\sim 0.15 \mathrm{mg} / \mathrm{L})$ at $4 \mathrm{~h}$, Transdermal: $27 \mathrm{ng} / \mathrm{mL}(\sim 0.03$ $\mathrm{mg} / \mathrm{L}) 4 \mathrm{~h}$ after birth, after $12 \mathrm{~h}$ back to baseline
Imaging: MRS Lac/NAA

reduction

Histology: Reduced CC3, lipid peroxidation (4HNE) and neuroinflammation (IBA-1)

Neurobehavioral: Improved outcomes in tone, suck, standing, establishing feeds in IV and transdermal patch
Reduction in cerebrospinal lipid peroxidation and IL1 $\beta$

$\mathrm{HI}$ is associated with 3-fold increase in melatonin levels, peak with 10 -fold increase at $24 \mathrm{~h}$
Imaging: Trend towards treatment effect on Day 1 (tissue volume and ADC) but lost at day 7, 20 and 43 Neurobehavioral: No treatment effect

Histology: No treatment effect rat model
Dose: $15 \mathrm{mg} / \mathrm{kg}$ IP, immediately after $\mathrm{HI}$, then $6 \mathrm{~h}$ and $25 \mathrm{~h}$ after Excipient: 5\% DMSO
No difference in outcomes in sex 
Table 2. Cont.

\begin{tabular}{|c|c|c|c|c|}
\hline Study & Model & $\begin{array}{c}\text { Dosing and Excipient } \\
\text { (Pharmacokinetics If Available) }\end{array}$ & Outcomes & Other Remarks \\
\hline $\begin{array}{l}\text { Sun et al. (2021) } \\
\text { [140] }\end{array}$ & $\begin{array}{l}\text { Rice-Vannucci } \\
\text { rat model }\end{array}$ & $\begin{array}{l}\text { Dose: } 10 \mathrm{mg} / \mathrm{kg} \text { IP immediately } \\
\text { after HI, then every } 24 \mathrm{~h} \text { for } 4 \\
\text { weeks } \\
\text { Excipient: Not reported }\end{array}$ & $\begin{array}{l}\text { Histology: Reduction in infarct } \\
\text { volume } \\
\text { Neurobehavioral: Improved } \\
\text { performance in learning and } \\
\text { memory, motor function and } \\
\text { co-ordination and forelimb grip }\end{array}$ & $\begin{array}{l}\text { Plppr5 gene } \\
\text { (neuronal } \\
\text { plasticity) } \\
\text { knockout } \\
\text { exacerbated } \\
\text { injury and } \\
\text { attenuated } \\
\text { neuroprotective } \\
\text { effects of } \\
\text { melatonin }\end{array}$ \\
\hline
\end{tabular}

4HNE $=$ 4-hydroxynonenal, $\mathrm{ADC}=$ Apparent diffusion coefficient, $\mathrm{AQ} 4=$ Aquaporin $4, \mathrm{DMSO}=$ Dimethyl Sulfoxide, GFAP $=$ Glial fibrillary acidic protein, $\mathrm{HI}=$ hypoxia-ischaemia, IBA-1= Ionised calcium binding adaptor molecule 1, IP = intraperitoneal, SIRT 1 = Sirtuin 1 , IV = intravenous, $\mathrm{ZO}-1$ = Zonula occludens-1.

There are some limitations of current animal models for NE in the LMIC setting. Tann et al. [147] reported neonatal bacteriaemia and histological funisitis as significant independent risk factors for NE in infants in Uganda. Infants born to mothers with chorioamnionitis are at increased risk of long-term neurological sequalae [148]. In our piglet model, LPS-sensitisation prior to HI was associated with increased severity of brain injury [149]. Rodent studies suggest that the response to neuroprotective interventions, following inflammation-sensitised $\mathrm{HI}$, may be pathogen specific; $\mathrm{HT}$ to $\mathrm{PAM}_{3} \mathrm{CSK}_{4}$ (gram positive) sensitised-HI was protective [150], but HT exacerbated brain injury in LPS sensitised-HI [151]. A further consideration is that current preclinical studies model an acute intrapartum HI event. However, patterns of injury on early cranial ultrasound imaging in Uganda suggest the onset of injury several hours before birth [152]. Predominant white matter injury on MRI in an observation study of NE infants in India [153] may also suggest a more chronic HI insult and/or exposure to perinatal inflammation. Preclinical studies assessing the efficacy of neuroprotective interventions in the context of perinatal inflammation and a more chronic, insidious onset of $\mathrm{HI}$ insults are needed.

\section{Translating from Bench to Bedside}

Although preclinical studies provide compelling evidence in the safety and efficacy of melatonin as a neuroprotective agent, clinical studies are limited. Ahmed et al. [21] reported a systematic review of clinical trials using melatonin as a single agent or in combination with HT for NE. The systematic review highlighted the lack of large, well-designed, and adequately powered randomised clinical trials in infants with NE [21] (Table 3).

To date, four of the five clinical trials [154-157] used the oral route of administration with variable doses of: $10 \mathrm{mg}$ once only [156], every $2 \mathrm{~h}$ for 4 doses [154], or $10 \mathrm{mg} / \mathrm{kg}$ daily for 5 days $[155,157]$ but the pharmacokinetic profiles in all studies were not reported. The oral bioavailability is less certain in newborns due to higher gastric $\mathrm{pH}$, lower superior mesenteric arterial blood flow and delayed gastric emptying [158]. In adults, the absolute oral bioavailability of melatonin has been reported to be 15\% [159]. Carloni et al. [160] observed serum melatonin levels of $7 \mathrm{mg} / \mathrm{L}$ were achievable with $5 \mathrm{mg} / \mathrm{kg}$ oral administration in preterm infants however, with a delay of $4 \mathrm{~h}$ to reach Cmax. The reduction in gastro-intestinal blood flow [161] and impaired gastrointestinal peristalsis, associated with infants with NE [162], will most likely impact the oral bioavailability of melatonin further. Given the narrow therapeutic window of melatonin, the intravenous route is the preferred route, as it provides the most predictable levels required for neuroprotection, bypassing the gastro-intestinal effects post $\mathrm{HI}$ and first passes metabolism in the liver. Neuroprotective agents given via the intranasal route has also received some interest [115] as it provides a more direct and rapid pathway to the brain, via the olfactory nerve and cribriform plate. Whilst this may reduce the melatonin dosing requirements and, therefore, exposure to 
the neurotoxic excipients, Van den Berg and colleagues [163] showed melatonin uptake in the CSF were similar between the intranasal and intravenous route. Highly concentrated melatonin formulations would be required to deliver therapeutic levels.

In the clinical melatonin trials, clinically relevant outcome measures were underreported; Aly et al. [155] observed improved survival without disability, albeit at 6 months, and Jerez-Calero et al. [164] showed improved cognitive outcomes on Bayley III neurodevelopmental assessment at 18 months in infants who received melatonin in combination with HT compared to HT alone, however the study was confounded by small sample size and a trend towards lower NE severity in the melatonin group. Consideration in future clinical design should also include surrogate biomarkers for outcomes in NE to accelerate clinical trials. ${ }^{1} \mathrm{H}$ MRS Lac/NAA peak ratio has been validated in both preclinical [46] and clinical studies $[44,124]$. Using a Lac/NAA threshold value of 0.39 , BGT Lac/NAA predicted 2-year neurodevelopment outcomes with high accuracy in infants who received HT for NE [44]. The TOBY-Xenon clinical trial, powered to detect a difference in the MRS Lac/NAA peak area ratio, recruited babies in January 2012 over 18 months, publishing in 2016 no biological effect based on difference in Lac/NAA (geometric mean difference of 1.09 (95\% CI 0.9-1.32)) [125]. Follow-up neurodevelopmental data at 2-3 years of age in 2019 showed that Lac/NAA accurately predicted adverse outcomes in $96 \%$ of cases [124].

Table 3. Randomised clinical trials using melatonin for neonatal encephalopathy in infants and relevant clinical outcomes.

\begin{tabular}{lll}
\hline \multicolumn{1}{c}{ Study } & \multicolumn{1}{c}{ Population } & \multicolumn{1}{c}{ Intervention } \\
\hline & & $\mathrm{N}=10$ \\
& Single centre, Italy & Melatonin alone \\
Fulia et al. (2001) & Diagnosis of perinatal & Dose: $80 \mathrm{mg}$ (10 mg 2 hourly) \\
[154] & $\begin{array}{l}\text { asphyxia within 6 h, } \\
\text { criteria not listed }\end{array}$ & $\begin{array}{l}\text { Route: Enteral } \\
\text { Excipient: } 1: 90 \text { ethanol:0.9\% } \\
\end{array}$ \\
& saline \\
\hline
\end{tabular}

$\begin{array}{ll} & \text { Single centre, Egypt } \\ \text { Aly et al. (2015) } & \text { HIE: Inborn, Apgar } \\ \text { score } \leq 3 \text { at } 5 \text { min, } \\ \text { BE }<12, \\ \text { moderate-severe NE }\end{array}$

\begin{tabular}{ll}
\multicolumn{1}{c}{ Comparison } & \multicolumn{1}{c}{ Clinical Outcomes } \\
& \\
$\mathrm{N}=10$ & $\begin{array}{l}\text { Mortality: RR 0.14 (95\% CI 0.01-2.45) } \\
\text { Imaging: Not reported } \\
\text { no HT }\end{array}$ \\
Neurodevelopment: Not reported
\end{tabular}
Mortality: RR 0.25 (95\% CI 0.03, 1.98)
EEG: melatonin had fewer seizures
$(3 / 14$ in $\mathrm{HT}+$ melatonin vs. $7 / 11$ in HT)
Imaging: MRI-less white matter
abnormalities $(0 / 14$ in HT + melatonin vs. $4 / 11$ in HT)
Neurodevelopment: Improved survival without abnormalities at 6 months $(10 / 14$ in $\mathrm{HT}+$ melatonin vs $3 / 11$ in HT)
$\mathrm{N}=15$
HT + Melatonin
Dose: $10 \mathrm{mg} / \mathrm{kg}$ daily for 5 days HT
Route: Enteral
Excipient: Distilled water

\begin{tabular}{|c|c|c|c|c|}
\hline $\begin{array}{l}\text { Ahmad et al. } \\
\text { (2018) [156] }\end{array}$ & $\begin{array}{l}\text { Single centre, Pakistan } \\
\text { Any HIE *: }>34 \text { weeks } \\
\text { gestation, based on } \\
\text { clinical features alone } \\
\text { * includes } 12.5 \% \text { mild } \\
\text { cases }\end{array}$ & $\begin{array}{l}\mathrm{N}=40 \\
\text { Melatonin alone } \\
\text { Dose: } 10 \mathrm{mg} \text { single dose } \\
\text { Route: Enteral } \\
\text { Excipient: Not reported }\end{array}$ & $\begin{array}{l}\mathrm{N}=40 \\
\text { Supportive care, } \\
\text { no HT }\end{array}$ & $\begin{array}{l}\text { Mortality: RR } 0.35(95 \% \text { CI } 0.14,0.90) \\
\text { all cases } \\
\text { Imaging: Not reported } \\
\text { Neurodevelopment: Not reported }\end{array}$ \\
\hline $\begin{array}{l}\text { El Farargy et al. } \\
\text { (2019) [157] }\end{array}$ & $\begin{array}{l}\text { Single centre, Egypt } \\
\text { HIE: Apgar score }<5 \\
\text { at } 5 \mathrm{~min} \text {, } \\
\text { Cord } \mathrm{pH}<7 \text { and /or } \\
\mathrm{BE} \geq 12 \mathrm{mmol} / \mathrm{L}) \text {, and } \\
\text { moderate } \mathrm{NE}\end{array}$ & $\begin{array}{l}\mathrm{N}=30 \\
\text { Melatonin + Magnesium } \\
\text { Sulphate } \\
\text { Dose: } 10 \mathrm{mg} / \mathrm{kg} \text { daily for } 5 \text { days } \\
\text { Route: Enteral } \\
\text { Excipient: Not reported }\end{array}$ & $\begin{array}{l}\mathrm{N}=30 \\
\text { Melatonin alone }\end{array}$ & $\begin{array}{l}\text { Mortality: Not reported } \\
\text { Imaging: Not reported } \\
\text { Neurodevelopment: Not reported }\end{array}$ \\
\hline $\begin{array}{l}\text { Jerez-Calero et al. } \\
(2020)[164]\end{array}$ & $\begin{array}{l}\text { Two centres, Spain } \\
\text { HIE: } \geq 36 \text { weeks } \\
\text { gestation, severe } \\
\text { perinatal asphyxia } \\
\text { (Apgar }<5 \text { at } 5 \text { min, } \\
\text { Cord } \mathrm{pH}<7 \text { and } / \text { or } \\
\mathrm{BE} \leq-16, \\
\text { Moderate-severe NE } \\
(\text { Sarnat score } \geq 6 \text { ) }\end{array}$ & $\begin{array}{l}\mathrm{N}=12 \\
\mathrm{HT}+\text { Melatonin } \\
\text { Dose: } 5 \mathrm{mg} / \mathrm{kg} \text { within } 6 \mathrm{~h} \text { of } \\
\text { birth, over } 2 \mathrm{~h} \text {, daily for } 3 \text { days } \\
\text { Route: IV } \\
\text { Excipient: propylene glycol + } \\
\text { macrogol }\end{array}$ & $\begin{array}{l}\mathrm{N}=13 \\
\mathrm{HT} \\
\text { servo-controlled, } \\
\text { Tecotherm cooling } \\
\text { device }\end{array}$ & $\begin{array}{l}\text { Mortality: RR } 1.0 \text { ( } 95 \% \text { CI } 0.07,14.21) \\
\text { aEEG: No difference in background } \\
\text { activity or seizure burden } \\
\text { Imaging: No difference in MRI } \\
\text { outcomes } \\
\text { Neurodevelopment: Improved } \\
\text { cognitive composite score }(p=0.05) \text { at } \\
18 \text { months on Bayley III Test, no other } \\
\text { significant differences }\end{array}$ \\
\hline
\end{tabular}


As we move towards translating melatonin from bench to bedside, several challenges remain in the drug development of suitable intravenous melatonin formulation prior to clinical trials. In general, any product used for clinical or therapeutic use should be produced to Good Manufacturing Practice (GMP); a regulation to ensure that the product is reproduceable and manufactured in a controlled environment. As the prevalence of NE is $<1$ in 2000 people, it is classified by the European Medicines Agency (EMA) as a rare disease, therefore eligible for Orphan Drug Designation (ODD). ODD supports pharmaceuticals by attracting investment when it is perceived that the commercial market is relatively small or the intellectual property surrounding the therapy is limited. In Europe, EMA provides access to the EMA central authorisation procedure and 10 years market exclusivity. The United States Food and Drug Administration (FDA) provide a comprehensive package including tax credits of up to $50 \%$ off the clinical drug testing cost awarded upon approval, fee waivers new drug application (NDA) or biologic licence applications (BLA) and 7 years market exclusivity.

\section{Conclusions}

The preclinical data for melatonin as a neuroprotective agent for NE is compelling. In our piglet model, we have shown, over several studies, that melatonin is safe and augments the neuroprotective benefit of cooling. Whilst promising, to the best of our knowledge, no other in-vivo animal studies have assessed the efficacy of melatonin in combination with HT. Our studies are limited to $48-72 \mathrm{~h}$ in duration, and longer-term studies to assess the neurobehavioral outcomes would further support our findings. Nonetheless, a key strength to our model is the use clinical outcomes such as aEEG and magnetic resonance spectroscopy Lac/NAA which are validated outcome biomarkers to predict neurodevelopmental outcomes in babies with NE. Other preclinical studies using melatonin as a single agent support its neuroprotective efficacy in NE.

The mechanism of action of melatonin is diverse, but for optimal effect, melatonin's antioxidant properties must be harnessed early in the neurotoxic cascade. Long-term effects of supra-physiological melatonin levels on the developing brain remains unknown. The reassuring physiological profile seen with high dose melatonin over the critical first 3 days of treatment in our pre-clinical models is encouraging. Infants with moderate to severe $\mathrm{NE}$ are at risk of significant mortality and morbidity; the time is now right for exploring melatonin in clinical neuroprotection trials.

Whilst the evidence for single agent melatonin therapy in preclinical animal studies of $\mathrm{NE}$ is valid, further studies in the context of inflammation-sensation and chronic $\mathrm{HI}$ are needed for the LMIC setting. The feasibility of intravenous administration and additional requirements, given the photosensitive nature of melatonin, should also be considered in this context. Robust PK studies are needed to establish the effect of $\mathrm{HI}$ on melatonin clearance in term infants.

The development of intravenous melatonin formulations with safe excipients (which may themselves be partially protective e.g., ethanol) for clinical use remains a key limiting step requiring the collaboration of neuroscientists, clinicians, pharmaceuticals, and research councils. In parallel, further preclinical studies are needed to identify a bundle of complementary neuroprotective agents and interventions targeting every aspect of the neurotoxic cascade to maximise the potential to change the trajectory of brain injury following perinatal HI. Agents targeting neuro-regeneration and repair (such as delayed Epo and stem-cells) to complement early melatonin administration holds promise and warrants further assessment in large recovery animal models.

Author Contributions: N.J.R. designed, secured funding, supervised, and interpreted data in the piglet studies reported in this review. R.P., A.A.-B., C.M., undertook the experiments and collected the data. R.P. organized and wrote the first draft of the manuscript. C.M. undertook microscopy, cell quantification, and analysed the immunohistochemistry results. X.G. assisted with MR physics aspects of the studies. D.J.F. advised on the translational aspects of this review. All authors have read and agreed to the published version of the manuscript. Images were created with BioRender. 
Funding: This research received a proportion of funding from the United Kingdom Department of Health's National Institute for Health Research Biomedical Research Centres Funding Scheme. The studies were funded by Wellbeing of Women, UK, Chiesi Pharmaceuticals S.p.A and the Medical Research Council (Grant References: MR/M006743/1, MR/P025978/1).

Institutional Review Board Statement: All animal studies were conducted according to United Kingdom Home Office Regulations [Animals (Scientific procedures) Act, 1986] and were approved by the ethics committee of University College London.

Informed Consent Statement: Not applicable.

Data Availability Statement: No new data were created or analysed in this study. Data sharing is not applicable to this article.

Conflicts of Interest: The authors declare no conflict of interest. The funders had no role in the design of the study; in the collection, analyses, or interpretation of data; in the writing of the manuscript, or in the decision to publish the results.

\section{References}

1. Lee, A.C.; Kozuki, N.; Blencowe, H.; Vos, T.; Bahalim, A.; Darmstadt, G.L.; Niermeyer, S.; Ellis, M.; Robertson, N.J.; Cousens, S.; et al. Intrapartum-related neonatal encephalopathy incidence and impairment at regional and global levels for 2010 with trends from 1990. Pediatr. Res. 2013, 74 (Suppl. 1), 50-72. [CrossRef]

2. Newton, C.R. Global Burden of Pediatric Neurological Disorders. Semin. Pediatr. Neurol. 2018, 27, 10-15. [CrossRef] [PubMed]

3. Gale, C.; Statnikov, Y.; Jawad, S.; Uthaya, S.N.; Modi, N.; Brain Injuries Expert Working Group. Neonatal brain injuries in England: Population-based incidence derived from routinely recorded clinical data held in the National Neonatal Research Database. Arch. Dis. Child. Fetal Neonatal Ed. 2018, 103, F301-F306. [CrossRef]

4. Royal College of Obstetrics Gynaecology. Each Baby Counts: 2018 Progress Report; RCOG: London, UK, 2018 ; pp. 1-10.

5. Kurinczuk, J.J.; White-Koning, M.; Badawi, N. Epidemiology of neonatal encephalopathy and hypoxic-ischaemic encephalopathy. Early Hum. Dev. 2010, 86, 329-338. [CrossRef] [PubMed]

6. Jacobs, S.E.; Berg, M.; Hunt, R.; Tarnow-Mordi, W.O.; Inder, T.E.; Davis, P.G. Cooling for newborns with hypoxic ischaemic encephalopathy. Cochrane Database Syst. Rev. 2013, CD003311. [CrossRef]

7. Shankaran, S.; Laptook, A.R.; Pappas, A.; McDonald, S.A.; Das, A.; Tyson, J.E.; Poindexter, B.B.; Schibler, K.; Bell, E.F.; Heyne, R.J.; et al. Effect of depth and duration of cooling on death or disability at age 18 months among neonates with hypoxic-ischemic encephalopathy: A randomized clinical trial. JAMA 2017, 318, 57-67. [CrossRef] [PubMed]

8. Jary, S.; Smit, E.; Liu, X.; Cowan, F.M.; Thoresen, M. Less severe cerebral palsy outcomes in infants treated with therapeutic hypothermia. Acta Paediatr. 2015, 104, 1241-1247. [CrossRef]

9. Shipley, L.; Gale, C.; Sharkey, D. Trends in the incidence and management of hypoxic-ischaemic encephalopathy in the therapeutic hypothermia era: A national population study. Arch. Dis. Child. Fetal Neonatal Ed. 2021. [CrossRef]

10. Lee-Kelland, R.; Jary, S.; Tonks, J.; Cowan, F.M.; Thoresen, M.; Chakkarapani, E. School-age outcomes of children without cerebral palsy cooled for neonatal hypoxic-ischaemic encephalopathy in 2008-2010. Arch. Dis. Child. Fetal Neonatal Ed. 2020, 105, 8-13. [CrossRef] [PubMed]

11. Spencer, A.P.C.; Brooks, J.C.W.; Masuda, N.; Byrne, H.; Lee-Kelland, R.; Jary, S.; Thoresen, M.; Tonks, J.; Goodfellow, M.; Cowan, F.M.; et al. Disrupted brain connectivity in children treated with therapeutic hypothermia for neonatal encephalopathy. NeuroImage Clin. 2021, 30. [CrossRef] [PubMed]

12. Iwata, O.; Thornton, J.S.; Sellwood, M.W.; Iwata, S.; Sakata, Y.; Noone, M.A.; O’Brien, F.E.; Bainbridge, A.; De Vita, E.; Raivich, G.; et al. Depth of delayed cooling alters neuroprotection pattern after hypoxia-ischemia. Ann. Neurol. 2005, 58, 75-87. [CrossRef] [PubMed]

13. Davidson, J.O.; Yuill, C.A.; Zhang, F.G.; Wassink, G.; Bennet, L.; Gunn, A.J. Extending the duration of hypothermia does not further improve white matter protection after ischemia in term-equivalent fetal sheep. Sci. Rep. 2016, 6, 25178. [CrossRef] [PubMed]

14. Alonso-Alconada, D.; Broad, K.D.; Bainbridge, A.; Chandrasekaran, M.; Faulkner, S.D.; Kerenyi, A.; Hassell, J.; Rocha-Ferreira, E.; Hristova, M.; Fleiss, B.; et al. Brain cell death is reduced with cooling by 3.5 degrees $C$ to 5 degrees $C$ but increased with cooling by 8.5 degrees $C$ in a piglet asphyxia model. Stroke 2015, 46, 275-278. [CrossRef] [PubMed]

15. Davies, A.; Wassink, G.; Bennet, L.; Gunn, A.J.; Davidson, J.O. Can we further optimize therapeutic hypothermia for hypoxicischemic encephalopathy? Neural Regen Res. 2019, 14, 1678-1683. [CrossRef]

16. Tann, C.J.; Webb, E.L.; Lassman, R.; Ssekyewa, J.; Sewegaba, M.; Musoke, M.; Burgoine, K.; Hagmann, C.; Deane-Bowers, E.; Norman, K.; et al. Early Childhood Outcomes After Neonatal Encephalopathy in Uganda: A Cohort Study. EClinicalMedicine 2018, 6, 26-35. [CrossRef] [PubMed]

17. Pauliah, S.S.; Shankaran, S.; Wade, A.; Cady, E.B.; Thayyil, S. Therapeutic hypothermia for neonatal encephalopathy in low- and middle-income countries: A systematic review and meta-analysis. PLoS ONE 2013, 8, e58834. [CrossRef] 
18. Thayyil, S.; Oliveira, V.; Lally, P.J.; Swamy, R.; Bassett, P.; Chandrasekaran, M.; Mondkar, J.; Mangalabharathi, S.; Benkappa, N.; Seeralar, A.; et al. Hypothermia for encephalopathy in low and middle-income countries (HELIX): Study protocol for a randomised controlled trial. Trials 2017, 18, 432. [CrossRef] [PubMed]

19. Wall, S.N.; Lee, A.C.; Carlo, W.; Goldenberg, R.; Niermeyer, S.; Darmstadt, G.L.; Keenan, W.; Bhutta, Z.A.; Perlman, J.; Lawn, J.E. Reducing intrapartum-related neonatal deaths in low- and middle-income countries-what works? Semin. Perinatol. 2010, 34, 395-407. [CrossRef]

20. Ramos, E.; Patino, P.; Reiter, R.J.; Gil-Martin, E.; Marco-Contelles, J.; Parada, E.; de Los Rios, C.; Romero, A.; Egea, J. Ischemic brain injury: New insights on the protective role of melatonin. Free Radic. Biol. Med. 2017, 104, 32-53. [CrossRef]

21. Ahmed, J.; Pullattayil, S.A.; Robertson, N.J.; More, K. Melatonin for neuroprotection in neonatal encephalopathy: A systematic review \& meta-analysis of clinical trials. Eur J. Paediatr. Neurol. 2021, 31, 38-45. [CrossRef]

22. Koehler, R.C.; Yang, Z.J.; Lee, J.K.; Martin, L.J. Perinatal hypoxic-ischemic brain injury in large animal models: Relevance to human neonatal encephalopathy. J. Cereb. Blood Flow Metab. 2018, 38, 2092-2111. [CrossRef] [PubMed]

23. Lingam, I.; Avdic-Belltheus, A.; Robertson, N.J. Using animal models to improve care of neonatal encephalopathy. Arch. Dis. Child. Educ. Pract. Ed. 2016, 101, 271-276. [CrossRef]

24. Reiter, R.J.; Tan, D.X.; Fuentes-Broto, L. Melatonin: A multitasking molecule. Prog. Brain Res. 2010, 181, 127-151. [CrossRef] [PubMed]

25. Lanoix, D.; Beghdadi, H.; Lafond, J.; Vaillancourt, C. Human placental trophoblasts synthesize melatonin and express its receptors. J. Pineal Res. 2008, 45, 50-60. [CrossRef] [PubMed]

26. Soliman, A.; Lacasse, A.A.; Lanoix, D.; Sagrillo-Fagundes, L.; Boulard, V.; Vaillancourt, C. Placental melatonin system is present throughout pregnancy and regulates villous trophoblast differentiation. J. Pineal Res. 2015, 59, 38-46. [CrossRef]

27. Nakamura, Y.; Tamura, H.; Kashida, S.; Takayama, H.; Yamagata, Y.; Karube, A.; Sugino, N.; Kato, H. Changes of serum melatonin level and its relationship to feto-placental unit during pregnancy. J. Pineal Res. 2001, 30, 29-33. [CrossRef] [PubMed]

28. Okatani, Y.; Okamoto, K.; Hayashi, K.; Wakatsuki, A.; Tamura, S.; Sagara, Y. Maternal-fetal transfer of melatonin in pregnant women near term. J. Pineal Res. 1998, 25, 129-134. [CrossRef]

29. Kennaway, D.J.; Goble, F.C.; Stamp, G.E. Factors influencing the development of melatonin rhythmicity in humans. J. Clin. Endocrinol. Metab. 1996, 81, 1525-1532. [CrossRef]

30. Sumida, M.; Barkovich, A.J.; Newton, T.H. Development of the pineal gland: Measurement with MR. AJNR Am. J. Neuroradiol. 1996, 17, 233-236. [PubMed]

31. Kennaway, D.J.; Stamp, G.E.; Goble, F.C. Development of melatonin production in infants and the impact of prematurity. J. Clin. Endocrinol. Metab. 1992, 75, 367-369. [CrossRef]

32. Biran, V.; Decobert, F.; Bednarek, N.; Boizeau, P.; Benoist, J.F.; Claustrat, B.; Barre, J.; Colella, M.; Frerot, A.; Garnotel, R.; et al. Melatonin Levels in Preterm and Term Infants and Their Mothers. Int. J. Mol. Sci. 2019, 20, 2077. [CrossRef]

33. Bubenik, G.A.; Pang, S.F. The role of serotonin and melatonin in gastrointestinal physiology: Ontogeny, regulation of food intake, and mutual serotonin-melatonin feedback. J. Pineal Res. 1994, 16, 91-99. [CrossRef]

34. Berbets, A.M.; Barbe, A.M.; Andriiets, O.A.; Andriiets, A.V.; Yuzko, O.M. Melatonin Levels Decrease in the Umbilical Cord in Case of Intrauterine Growth Restriction. J. Med. Life 2020, 13, 548-553. [CrossRef] [PubMed]

35. Tauman, R.; Zisapel, N.; Laudon, M.; Nehama, H.; Sivan, Y. Melatonin production in infants. Pediatr. Neurol. 2002, 26, 379-382. [CrossRef]

36. Azzopardi, D.; Wyatt, J.S.; Cady, E.B.; Delpy, D.T.; Baudin, J.; Stewart, A.L.; Hope, P.L.; Hamilton, P.A.; Reynolds, E.O. Prognosis of newborn infants with hypoxic-ischemic brain injury assessed by phosphorus magnetic resonance spectroscopy. Pediatr. Res. 1989, 25, 445-451. [CrossRef] [PubMed]

37. Robertson, N.J.; Cox, I.J.; Cowan, F.M.; Counsell, S.J.; Azzopardi, D.; Edwards, A.D. Cerebral intracellular lactic alkalosis persisting months after neonatal encephalopathy measured by magnetic resonance spectroscopy. Pediatr. Res. 1999, 46, 287-296. [CrossRef]

38. Robertson, N.J.; Cowan, F.M.; Cox, I.J.; Edwards, A.D. Brain alkaline intracellular pH after neonatal encephalopathy. Ann. Neurol. 2002, 52, 732-742. [CrossRef]

39. Penrice, J.; Cady, E.B.; Lorek, A.; Wylezinska, M.; Amess, P.N.; Aldridge, R.F.; Stewart, A.; Wyatt, J.S.; Reynolds, E.O. Proton magnetic resonance spectroscopy of the brain in normal preterm and term infants, and early changes after perinatal hypoxiaischemia. Pediatr. Res. 1996, 40, 6-14. [CrossRef] [PubMed]

40. Lorek, A.; Takei, Y.; Cady, E.B.; Wyatt, J.S.; Penrice, J.; Edwards, A.D.; Peebles, D.; Wylezinska, M.; Owen-Reece, H.; Kirkbride, V.; et al. Delayed ("secondary") cerebral energy failure after acute hypoxia-ischemia in the newborn piglet: Continuous 48-h studies by phosphorus magnetic resonance spectroscopy. Pediatr. Res. 1994, 36, 699-706. [CrossRef]

41. Penrice, J.; Lorek, A.; Cady, E.B.; Amess, P.N.; Wylezinska, M.; Cooper, C.E.; D’Souza, P.; Brown, G.C.; Kirkbride, V.; Edwards, A.D.; et al. Proton magnetic resonance spectroscopy of the brain during acute hypoxia-ischemia and delayed cerebral energy failure in the newborn piglet. Pediatr. Res. 1997, 41, 795-802. [CrossRef] [PubMed]

42. Roth, S.C.; Baudin, J.; Cady, E.; Johal, K.; Townsend, J.P.; Wyatt, J.S.; Reynolds, E.O.; Stewart, A.L. Relation of deranged neonatal cerebral oxidative metabolism with neurodevelopmental outcome and head circumference at 4 years. Dev. Med. Child. Neurol. 1997, 39, 718-725. [CrossRef] 
43. Roth, S.C.; Edwards, A.D.; Cady, E.B.; Delpy, D.T.; Wyatt, J.S.; Azzopardi, D.; Baudin, J.; Townsend, J.; Stewart, A.L.; Reynolds, E.O. Relation between cerebral oxidative metabolism following birth asphyxia, and neurodevelopmental outcome and brain growth at one year. Dev. Med. Child. Neurol. 1992, 34, 285-295. [CrossRef]

44. Mitra, S.; Kendall, G.S.; Bainbridge, A.; Sokolska, M.; Dinan, M.; Uria-Avellanal, C.; Price, D.; McKinnon, K.; Gunny, R.; HuertasCeballos, A.; et al. Proton magnetic resonance spectroscopy lactate/ $\mathrm{N}$-acetylaspartate within 2 weeks of birth accurately predicts 2-year motor, cognitive and language outcomes in neonatal encephalopathy after therapeutic hypothermia. Arch. Dis. Child. Fetal Neonatal Ed. 2019, 104, F424-F432. [CrossRef] [PubMed]

45. Fleiss, B.; Gressens, P. Tertiary mechanisms of brain damage: A new hope for treatment of cerebral palsy? Lancet Neurol. 2012, 11, 556-566. [CrossRef]

46. Pang, R.; Martinello, K.A.; Meehan, C.; Avdic-Belltheus, A.; Lingam, I.; Sokolska, M.; Mutshiya, T.; Bainbridge, A.; Golay, X.; Robertson, N.J. Proton Magnetic Resonance Spectroscopy Lactate/N-Acetylaspartate Within 48 h Predicts Cell Death Following Varied Neuroprotective Interventions in a Piglet Model of Hypoxia-Ischemia With and Without Inflammation-Sensitization. Front. Neurol. 2020, 11, 883. [CrossRef] [PubMed]

47. Wassink, G.; Gunn, E.R.; Drury, P.P.; Bennet, L.; Gunn, A.J. The mechanisms and treatment of asphyxial encephalopathy. Front. Neurosci. 2014, 8, 40. [CrossRef] [PubMed]

48. Gunn, A.J.; Thoresen, M. Neonatal encephalopathy and hypoxic-ischemic encephalopathy. Handb. Clin. Neurol. 2019, 162, $217-237$. [CrossRef] [PubMed]

49. Greco, P.; Nencini, G.; Piva, I.; Scioscia, M.; Volta, C.A.; Spadaro, S.; Neri, M.; Bonaccorsi, G.; Greco, F.; Cocco, I.; et al. Pathophysiology of hypoxic-ischemic encephalopathy: A review of the past and a view on the future. Acta Neurol. Belg. 2020, 120, 277-288. [CrossRef]

50. Hassell, K.J.; Reiter, R.J.; Robertson, N.J. Melatonin and Its Role in Neurodevelopment during the Perinatal Period: A Review. Fetal Matern. Med. Rev. 2013, 24, 76-107. [CrossRef]

51. Tarocco, A.; Caroccia, N.; Morciano, G.; Wieckowski, M.R.; Ancora, G.; Garani, G.; Pinton, P. Melatonin as a master regulator of cell death and inflammation: Molecular mechanisms and clinical implications for newborn care. Cell Death Dis. 2019, 10, 317. [CrossRef]

52. Qin, X.; Cheng, J.; Zhong, Y.; Mahgoub, O.K.; Akter, F.; Fan, Y.; Aldughaim, M.; Xie, Q.; Qin, L.; Gu, L.; et al. Mechanism and Treatment Related to Oxidative Stress in Neonatal Hypoxic-Ischemic Encephalopathy. Front. Mol. Neurosci. 2019, 12, 88. [CrossRef] [PubMed]

53. Negro, S.; Benders, M.; Tataranno, M.L.; Coviello, C.; de Vries, L.S.; van Bel, F.; Groenendaal, F.; Longini, M.; Proietti, F.; Belvisi, E.; et al. Early Prediction of Hypoxic-Ischemic Brain Injury by a New Panel of Biomarkers in a Population of Term Newborns. Oxid. Med. Cell Longev. 2018, 2018, 7608108. [CrossRef]

54. Miller, S.L.; Yan, E.B.; Castillo-Melendez, M.; Jenkin, G.; Walker, D.W. Melatonin provides neuroprotection in the late-gestation fetal sheep brain in response to umbilical cord occlusion. Dev. Neurosci. 2005, 27, 200-210. [CrossRef] [PubMed]

55. Rodriguez, M.; Valez, V.; Cimarra, C.; Blasina, F.; Radi, R. Hypoxic-Ischemic Encephalopathy and Mitochondrial Dysfunction: Facts, Unknowns, and Challenges. Antioxid. Redox Signal. 2020, 33, 247-262. [CrossRef]

56. Hagberg, H. Mitochondrial impairment in the developing brain after hypoxia-ischemia. J. Bioenergy Biomembr. 2004, 36, 369-373. [CrossRef]

57. Favie, L.M.A.; Cox, A.R.; van den Hoogen, A.; Nijboer, C.H.A.; Peeters-Scholte, C.; van Bel, F.; Egberts, T.C.G.; Rademaker, C.M.A.; Groenendaal, F. Nitric Oxide Synthase Inhibition as a Neuroprotective Strategy Following Hypoxic-Ischemic Encephalopathy: Evidence From Animal Studies. Front. Neurol. 2018, 9, 258. [CrossRef] [PubMed]

58. Kaur, C.; Sivakumar, V.; Lu, J.; Tang, F.R.; Ling, E.A. Melatonin attenuates hypoxia-induced ultrastructural changes and increased vascular permeability in the developing hippocampus. Brain Pathol. 2008, 18, 533-547. [CrossRef] [PubMed]

59. Signorini, C.; Ciccoli, L.; Leoncini, S.; Carloni, S.; Perrone, S.; Comporti, M.; Balduini, W.; Buonocore, G. Free iron, total Fisoprostanes and total F-neuroprostanes in a model of neonatal hypoxic-ischemic encephalopathy: Neuroprotective effect of melatonin. J. Pineal Res. 2009, 46, 148-154. [CrossRef]

60. Balduini, W.; Carloni, S.; Perrone, S.; Bertrando, S.; Tataranno, M.L.; Negro, S.; Proietti, F.; Longini, M.; Buonocore, G. The use of melatonin in hypoxic-ischemic brain damage: An experimental study. J. Matern. Fetal Neonatal Med. 2012, 25 (Suppl. 1), $119-124$. [CrossRef]

61. Yawno, T.; Mahen, M.; Li, J.; Fahey, M.C.; Jenkin, G.; Miller, S.L. The Beneficial Effects of Melatonin Administration Following Hypoxia-Ischemia in Preterm Fetal Sheep. Front. Cell Neurosci. 2017, 11, 296. [CrossRef]

62. Aridas, J.D.S.; Yawno, T.; Sutherland, A.E.; Nitsos, I.; Ditchfield, M.; Wong, F.Y.; Hunt, R.W.; Fahey, M.C.; Malhotra, A.; Wallace, E.M.; et al. Systemic and transdermal melatonin administration prevents neuropathology in response to perinatal asphyxia in newborn lambs. J. Pineal Res. 2018, 64, e12479. [CrossRef] [PubMed]

63. Galano, A.; Tan, D.X.; Reiter, R.J. On the free radical scavenging activities of melatonin's metabolites, AFMK and AMK. J. Pineal Res. 2013, 54, 245-257. [CrossRef] [PubMed]

64. Tan, D.X.; Manchester, L.C.; Terron, M.P.; Flores, L.J.; Reiter, R.J. One molecule, many derivatives: A never-ending interaction of melatonin with reactive oxygen and nitrogen species? J. Pineal Res. 2007, 42, 28-42. [CrossRef] [PubMed]

65. Reina, M.; Martínez, A. A new free radical scavenging cascade involving melatonin and three of its metabolites (3OHM, AFMK and AMK). Comput. Theor. Chem. 2018, 1123, 111-118. [CrossRef] 
66. Northington, F.J.; Zelaya, M.E.; O’Riordan, D.P.; Blomgren, K.; Flock, D.L.; Hagberg, H.; Ferriero, D.M.; Martin, L.J. Failure to complete apoptosis following neonatal hypoxia-ischemia manifests as "continuum" phenotype of cell death and occurs with multiple manifestations of mitochondrial dysfunction in rodent forebrain. Neuroscience 2007, 149, 822-833. [CrossRef]

67. Carloni, S.; Carnevali, A.; Cimino, M.; Balduini, W. Extended role of necrotic cell death after hypoxia-ischemia-induced neurodegeneration in the neonatal rat. Neurobiol. Dis. 2007, 27, 354-361. [CrossRef]

68. Galluzzi, L.; Vitale, I.; Aaronson, S.A.; Abrams, J.M.; Adam, D.; Agostinis, P.; Alnemri, E.S.; Altucci, L.; Amelio, I.; Andrews, D.W.; et al. Molecular mechanisms of cell death: Recommendations of the Nomenclature Committee on Cell Death 2018. Cell Death Differ. 2018, 25, 486-541. [CrossRef]

69. Hunter, D.R.; Haworth, R.A. The $\mathrm{Ca}^{2+}$-induced membrane transition in mitochondria. I. The protective mechanisms. Arch Biochem. Biophys. 1979, 195, 453-459. [CrossRef]

70. Sun, F.Y.; Lin, X.; Mao, L.Z.; Ge, W.H.; Zhang, L.M.; Huang, Y.L.; Gu, J. Neuroprotection by melatonin against ischemic neuronal injury associated with modulation of DNA damage and repair in the rat following a transient cerebral ischemia. J. Pineal Res. 2002, 33, 48-56. [CrossRef]

71. Sinha, B.; Wu, Q.; Li, W.; Tu, Y.; Sirianni, A.C.; Chen, Y.; Jiang, J.; Zhang, X.; Chen, W.; Zhou, S.; et al. Protection of melatonin in experimental models of newborn hypoxic-ischemic brain injury through MT1 receptor. J. Pineal Res. 2018, 64. [CrossRef] [PubMed]

72. Zhou, H.; Li, D.; Zhu, P.; Ma, Q.; Toan, S.; Wang, J.; Hu, S.; Chen, Y.; Zhang, Y. Inhibitory effect of melatonin on necroptosis via repressing the Ripk3-PGAM5-CypD-mPTP pathway attenuates cardiac microvascular ischemia-reperfusion injury. J. Pineal Res. 2018, 65, e12503. [CrossRef] [PubMed]

73. Fang, Y.; Zhao, C.; Xiang, H.; Zhao, X.; Zhong, R. Melatonin Inhibits Formation of Mitochondrial Permeability Transition Pores and Improves Oxidative Phosphorylation of Frozen-Thawed Ram Sperm. Front. Endocrinol. 2019, 10, 896. [CrossRef]

74. Charriaut-Marlangue, C.; Besson, V.C.; Baud, O. Sexually Dimorphic Outcomes after Neonatal Stroke and Hypoxia-Ischemia. Int. J. Mol. Sci. 2017, 19, 61. [CrossRef] [PubMed]

75. Lin, K.C.; Chen, K.H.; Wallace, C.G.; Chen, Y.L.; Ko, S.F.; Lee, M.S.; Yip, H.K. Combined Therapy With Hyperbaric Oxygen and Melatonin Effectively Reduce Brain Infarct Volume and Preserve Neurological Function After Acute Ischemic Infarct in Rat. J. Neuropathol. Exp. Neurol. 2019, 78, 949-960. [CrossRef]

76. Leavy, A.; Jimenez Mateos, E.M. Perinatal Brain Injury and Inflammation: Lessons from Experimental Murine Models. Cells 2020, 9, 2640. [CrossRef] [PubMed]

77. Lingam, I.; Avdic-Belltheus, A.; Meehan, C.; Martinello, K.; Ragab, S.; Peebles, D.; Barkhuizen, M.; Tann, C.J.; Tachtsidis, I.; Wolfs, T.; et al. Serial blood cytokine and chemokine mRNA and microRNA over $48 \mathrm{~h}$ are insult specific in a piglet model of inflammation-sensitized hypoxia-ischaemia. Pediatr. Res. 2020. [CrossRef]

78. Rocha-Ferreira, E.; Kelen, D.; Faulkner, S.; Broad, K.D.; Chandrasekaran, M.; Kerenyi, A.; Kato, T.; Bainbridge, A.; Golay, X.; Sullivan, M.; et al. Systemic pro-inflammatory cytokine status following therapeutic hypothermia in a piglet hypoxia-ischemia model. J. Neuroinflamm. 2017, 14, 44. [CrossRef]

79. Chalak, L.F.; Sanchez, P.J.; Adams-Huet, B.; Laptook, A.R.; Heyne, R.J.; Rosenfeld, C.R. Biomarkers for severity of neonatal hypoxic-ischemic encephalopathy and outcomes in newborns receiving hypothermia therapy. J. Pediatr. 2014, 164, 468-474.e461. [CrossRef]

80. Jenkins, D.D.; Rollins, L.G.; Perkel, J.K.; Wagner, C.L.; Katikaneni, L.P.; Bass, W.T.; Kaufman, D.A.; Horgan, M.J.; Languani, S.; Givelichian, L.; et al. Serum cytokines in a clinical trial of hypothermia for neonatal hypoxic-ischemic encephalopathy. J. Cereb. Blood Flow Metab. 2012, 32, 1888-1896. [CrossRef] [PubMed]

81. O'Hare, F.M.; Watson, R.W.; O’Neill, A.; Segurado, R.; Sweetman, D.; Downey, P.; Mooney, E.; Murphy, J.; Donoghue, V.; Molloy, E.J. Serial cytokine alterations and abnormal neuroimaging in newborn infants with encephalopathy. Acta Paediatr. 2017, 106, 561-567. [CrossRef]

82. Savard, A.; Brochu, M.E.; Chevin, M.; Guiraut, C.; Grbic, D.; Sebire, G. Neuronal self-injury mediated by IL-1beta and MMP-9 in a cerebral palsy model of severe neonatal encephalopathy induced by immune activation plus hypoxia-ischemia. J. Neuroinflamm. 2015, 12, 111. [CrossRef]

83. Quinlan, S.; Merino-Serrais, P.; Di Grande, A.; Dussmann, H.; Prehn, J.H.M.; Ni Chonghaile, T.; Henshall, D.C.; Jimenez-Mateos, E.M. The Anti-inflammatory Compound Candesartan Cilexetil Improves Neurological Outcomes in a Mouse Model of Neonatal Hypoxia. Front. Immunol. 2019, 10, 1752. [CrossRef]

84. Tang, Z.; Cheng, S.; Sun, Y.; Zhang, Y.; Xiang, X.; Ouyang, Z.; Zhu, X.; Wang, B.; Hei, M. Early TLR4 inhibition reduces hippocampal injury at puberty in a rat model of neonatal hypoxic-ischemic brain damage via regulation of neuroimmunity and synaptic plasticity. Exp. Neurol. 2019, 321, 113039. [CrossRef]

85. Blanco, S.; Hernandez, R.; Franchelli, G.; Ramos-Alvarez, M.M.; Peinado, M.A. Melatonin influences NO/NOS pathway and reduces oxidative and nitrosative stress in a model of hypoxic-ischemic brain damage. Nitric Oxide 2017, 62, 32-43. [CrossRef] [PubMed]

86. Yao, L.; Lu, P.; Ling, E.A. Melatonin Suppresses Toll Like Receptor 4-Dependent Caspase-3 Signaling Activation Coupled with Reduced Production of Proinflammatory Mediators in Hypoxic Microglia. PLoS ONE 2016, 11, e0166010. [CrossRef] 
87. Farre-Alins, V.; Narros-Fernandez, P.; Palomino-Antolin, A.; Decouty-Perez, C.; Lopez-Rodriguez, A.B.; Parada, E.; MunozMontero, A.; Gomez-Rangel, V.; Lopez-Munoz, F.; Ramos, E.; et al. Melatonin Reduces NLRP3 Inflammasome Activation by Increasing alpha7 nAChR-Mediated Autophagic Flux. Antioxidants 2020, 9, 1299. [CrossRef]

88. Merlo, S.; Luaces, J.P.; Spampinato, S.F.; Toro-Urrego, N.; Caruso, G.I.; D’Amico, F.; Capani, F.; Sortino, M.A. SIRT1 Mediates Melatonin's Effects on Microglial Activation in Hypoxia: In Vitro and In Vivo Evidence. Biomolecules 2020, 10, 364. [CrossRef]

89. Slominski, R.M.; Reiter, R.J.; Schlabritz-Loutsevitch, N.; Ostrom, R.S.; Slominski, A.T. Melatonin membrane receptors in peripheral tissues: Distribution and functions. Mol. Cell Endocrinol. 2012, 351, 152-166. [CrossRef]

90. Lacoste, B.; Angeloni, D.; Dominguez-Lopez, S.; Calderoni, S.; Mauro, A.; Fraschini, F.; Descarries, L.; Gobbi, G. Anatomical and cellular localization of melatonin MT1 and MT2 receptors in the adult rat brain. J. Pineal Res. 2015, 58, 397-417. [CrossRef] [PubMed]

91. Klosen, P.; Lapmanee, S.; Schuster, C.; Guardiola, B.; Hicks, D.; Pevet, P.; Felder-Schmittbuhl, M.P. MT1 and MT2 melatonin receptors are expressed in nonoverlapping neuronal populations. J. Pineal Res. 2019, 67, e12575. [CrossRef] [PubMed]

92. Suofu, Y.; Li, W.; Jean-Alphonse, F.G.; Jia, J.; Khattar, N.K.; Li, J.; Baranov, S.V.; Leronni, D.; Mihalik, A.C.; He, Y.; et al. Dual role of mitochondria in producing melatonin and driving GPCR signaling to block cytochrome c release. Proc. Natl. Acad. Sci. USA 2017, 114, E7997-E8006. [CrossRef]

93. Ng, K.Y.; Leong, M.K.; Liang, H.; Paxinos, G. Melatonin receptors: Distribution in mammalian brain and their respective putative functions. Brain Struct. Funct. 2017, 222, 2921-2939. [CrossRef]

94. Hashimoto, T.; Nakai, M. Increased hippocampal quinone reductase 2 in Alzheimer's disease. Neurosci. Lett. 2011, 502, 10-12. [CrossRef] [PubMed]

95. Rappaport, A.N.; Jacob, E.; Sharma, V.; Inberg, S.; Elkobi, A.; Ounallah-Saad, H.; Pasmanik-Chor, M.; Edry, E.; Rosenblum, K. Expression of Quinone Reductase-2 in the Cortex Is a Muscarinic Acetylcholine Receptor-Dependent Memory Consolidation Constraint. J. Neurosci. 2015, 35, 15568-15581. [CrossRef] [PubMed]

96. Cassagnes, L.E.; Chhour, M.; Perio, P.; Sudor, J.; Gayon, R.; Ferry, G.; Boutin, J.A.; Nepveu, F.; Reybier, K. Oxidative stress and neurodegeneration: The possible contribution of quinone reductase 2. Free Radic. Biol. Med. 2018, 120, 56-61. [CrossRef] [PubMed]

97. Jeong, J.K.; Park, S.Y. Melatonin regulates the autophagic flux via activation of alpha-7 nicotinic acetylcholine receptors. J. Pineal Res. 2015, 59, 24-37. [CrossRef] [PubMed]

98. Robertson, N.J.; Faulkner, S.; Fleiss, B.; Bainbridge, A.; Andorka, C.; Price, D.; Powell, E.; Lecky-Thompson, L.; Thei, L.; Chandrasekaran, M.; et al. Melatonin augments hypothermic neuroprotection in a perinatal asphyxia model. Brain 2013, 136, 90-105. [CrossRef] [PubMed]

99. Robertson, N.J.; Martinello, K.; Lingam, I.; Avdic-Belltheus, A.; Meehan, C.; Alonso-Alconada, D.; Ragab, S.; Bainbridge, A.; Sokolska, M.; Tachrount, M.; et al. Melatonin as an adjunct to therapeutic hypothermia in a piglet model of neonatal encephalopathy: A translational study. Neurobiol. Dis. 2019, 121, 240-251. [CrossRef] [PubMed]

100. Robertson, N.J.; Lingam, I.; Meehan, C.; Martinello, K.A.; Avdic-Belltheus, A.; Stein, L.; Tachrount, M.; Price, D.; Sokolska, M.; Bainbridge, A.; et al. High-dose melatonin and ethanol excipient combined with therapeutic hypothermia in a newborn piglet asphyxia model. Sci. Rep. 2020, 10, 3898. [CrossRef]

101. Pang, R.; Avdic-Belltheus, A.; Meehan, C.; Martinello, K.; Mutshiya, T.; Yang, Q.; Sokolska, M.; Torrealdea, F.; Hristova, M.; Bainbridge, A.; et al. Melatonin and/or erythropoietin combined with hypothermia in a piglet model of perinatal asphyxia. Brain Commun. 2021, 3. [CrossRef] [PubMed]

102. Carloni, S.; Facchinetti, F.; Pelizzi, N.; Buonocore, G.; Balduini, W. Melatonin acts in synergy with hypothermia to reduce oxygen-glucose deprivation-induced cell death in rat hippocampus organotypic slice cultures. Neonatology 2018, 114, 364-371. [CrossRef]

103. Drury, P.P.; Davidson, J.O.; Bennet, L.; Booth, L.C.; Tan, S.; Fraser, M.; van den Heuij, L.G.; Gunn, A.J. Partial neural protection with prophylactic low-dose melatonin after asphyxia in preterm fetal sheep. J. Cereb. Blood Flow Metab. 2014, 34, 126-135. [CrossRef] [PubMed]

104. Hosokawa, K.; Su, F.; Taccone, F.S.; Post, E.H.; Creteur, J.; Vincent, J.L. Effects of acute ethanol intoxication in an ovine peritonitis model. BMC Anesthesiol. 2018, 18, 70. [CrossRef]

105. El-Mas, M.M.; Fan, M.; Abdel-Rahman, A.A. Endotoxemia-mediated induction of cardiac inducible nitric-oxide synthase expression accounts for the hypotensive effect of ethanol in female rats. J. Pharmacol. Exp. Ther. 2008, 324, 368-375. [CrossRef]

106. El-Mas, M.M.; Zhang, J.; Abdel-Rahman, A.A. Upregulation of vascular inducible nitric oxide synthase mediates the hypotensive effect of ethanol in conscious female rats. J. Appl. Physiol. 2006, 100, 1011-1018. [CrossRef]

107. Ajisaka, H.; Okajima, M.; Goto, Y.; Taniguchi, T.; Inaba, H. Effects of acute low-dose ethanol on inflammatory reactions to endotoxin-induced shock in rats. J. Toxicol. Sci. 2012, 37, 649-654. [CrossRef]

108. Wozniak, J.R.; Riley, E.P.; Charness, M.E. Clinical presentation, diagnosis, and management of fetal alcohol spectrum disorder. Lancet Neurol. 2019, 18, 760-770. [CrossRef]

109. Valeur, K.S.; Hertel, S.A.; Lundstrom, K.E.; Holst, H. The Cumulative Daily Tolerance Levels of Potentially Toxic Excipients Ethanol and Propylene Glycol Are Commonly Exceeded in Neonates and Infants. Basic Clin. Pharmacol. Toxicol. 2018, 122, 523-530. [CrossRef] 
110. Kochanski, R.; Peng, C.; Higashida, T.; Geng, X.; Huttemann, M.; Guthikonda, M.; Ding, Y. Neuroprotection conferred by post-ischemia ethanol therapy in experimental stroke: An inhibitory effect on hyperglycolysis and NADPH oxidase activation. $J$. Neurochem. 2013, 126, 113-121. [CrossRef]

111. Abbasi, Y.; Shabani, R.; Mousavizadeh, K.; Soleimani, M.; Mehdizadeh, M. Neuroprotective effect of ethanol and Modafinil on focal cerebral ischemia in rats. Metab. Brain Dis. 2019, 34, 805-819. [CrossRef]

112. Geng, X.; Fu, P.; Ji, X.; Peng, C.; Fredrickson, V.; Sy, C.; Meng, R.; Ling, F.; Du, H.; Tan, X.; et al. Synergetic neuroprotection of normobaric oxygenation and ethanol in ischemic stroke through improved oxidative mechanism. Stroke 2013, 44, 1418-1425. [CrossRef] [PubMed]

113. Parmar, S.; Moore-Langston, S.; Fredrickson, V.; Kim, J.M.; Rastogi, R.; Elmadoun, O.; Ding, Y. Neuroprotective mechanisms of oxygen and ethanol: A potential combination therapy in stroke. Curr. Med. Chem. 2015, 22, 1194-1204. [CrossRef]

114. Yuan, Y.; Peng, C.; Li, K.; Hussain, M.; Sikharam, C.; Guthikonda, M.; Ding, Y. Ethanol reduces expression of apoptotic proteins after hypoxia/reoxygenation in a brain slice model. Neurol. Res. 2012, 34, 373-378. [CrossRef] [PubMed]

115. Robertson, N.J.; Meehan, C.; Martinello, K.A.; Avdic-Belltheus, A.; Boggini, T.; Mutshiya, T.; Lingam, I.; Yang, Q.; Sokolska, M.; Charalambous, X.; et al. Human umbilical cord mesenchymal stromal cells as an adjunct therapy with therapeutic hypothermia in a piglet model of perinatal asphyxia. Cytotherapy 2020. [CrossRef]

116. Andrisano, V.; Bertucci, C.; Battaglia, A.; Cavrini, V. Photostability of drugs: Photodegradation of melatonin and its determination in commercial formulations. J. Pharm. Biomed. Anal. 2000, 23, 15-23. [CrossRef]

117. Merchant, N.M.; Azzopardi, D.V.; Hawwa, A.F.; McElnay, J.C.; Middleton, B.; Arendt, J.; Arichi, T.; Gressens, P.; Edwards, A.D. Pharmacokinetics of melatonin in preterm infants. Br. J. Clin. Pharmacol. 2013, 76, 725-733. [CrossRef] [PubMed]

118. Balduini, W.; Weiss, M.D.; Carloni, S.; Rocchi, M.; Sura, L.; Rossignol, C.; Longini, M.; Bazzini, F.; Perrone, S.; Ott, D.; et al. Melatonin pharmacokinetics and dose extrapolation after enteral infusion in neonates subjected to hypothermia. J. Pineal Res. 2019, 66, e12565. [CrossRef] [PubMed]

119. Gitto, E.; Reiter, R.J.; Amodio, A.; Romeo, C.; Cuzzocrea, E.; Sabatino, G.; Buonocore, G.; Cordaro, V.; Trimarchi, G.; Barberi, I. Early indicators of chronic lung disease in preterm infants with respiratory distress syndrome and their inhibition by melatonin. J. Pineal Res. 2004, 36, 250-255. [CrossRef] [PubMed]

120. Jan, J.E.; Wasdell, M.B.; Freeman, R.D.; Bax, M. Evidence supporting the use of melatonin in short gestation infants. J. Pineal Res. 2007, 42, 22-27. [CrossRef]

121. Martin, L.J.; Brambrink, A.; Koehler, R.C.; Traystman, R.J. Primary sensory and forebrain motor systems in the newborn brain are preferentially damaged by hypoxia-ischemia. J. Comp. Neurol. 1997, 377, 262-285. [CrossRef]

122. Faulkner, S.; Bainbridge, A.; Kato, T.; Chandrasekaran, M.; Kapetanakis, A.B.; Hristova, M.; Liu, M.; Evans, S.; De Vita, E.; Kelen, D.; et al. Xenon augmented hypothermia reduces early lactate/ $\mathrm{N}$-acetylaspartate and cell death in perinatal asphyxia. Ann. Neurol. 2011, 70, 133-150. [CrossRef] [PubMed]

123. Chakkarapani, E.; Dingley, J.; Liu, X.; Hoque, N.; Aquilina, K.; Porter, H.; Thoresen, M. Xenon enhances hypothermic neuroprotection in asphyxiated newborn pigs. Ann. Neurol. 2010, 68, 330-341. [CrossRef]

124. Azzopardi, D.; Chew, A.T.; Deierl, A.; Huertas, A.; Robertson, N.J.; Tusor, N.; Edwards, A.D. Prospective qualification of early cerebral biomarkers in a randomised trial of treatment with xenon combined with moderate hypothermia after birth asphyxia. EBioMedicine 2019, 47, 484-491. [CrossRef] [PubMed]

125. Azzopardi, D.; Robertson, N.J.; Bainbridge, A.; Cady, E.; Charles-Edwards, G.; Deierl, A.; Fagiolo, G.; Franks, N.P.; Griffiths, J.; Hajnal, J.; et al. Moderate hypothermia within $6 \mathrm{~h}$ of birth plus inhaled xenon versus moderate hypothermia alone after birth asphyxia (TOBY-Xe): A proof-of-concept, open-label, randomised controlled trial. Lancet Neurol. 2016, 15, 145-153. [CrossRef]

126. National Health and Medical Research Council, Australia. PAEAN_Erythropoietin for Hypoxic Ischaemic Encephalopathy in Newborns. Available online: https: / clinicaltrials.gov/ct2/ show / NCT03079167?id=NCT03079167\&draw=2\&rank=1\&load=cart (accessed on 15 April 2021).

127. Juul, S.E.; Comstock, B.A.; Heagerty, P.J.; Mayock, D.E.; Goodman, A.M.; Hauge, S.; Gonzalez, F.; Wu, Y.W. High-dose erythropoietin for asphyxia and encephalopathy (HEAL): A randomized controlled trial—Background, aims, and study protocol. Neonatology 2018, 113, 331-338. [CrossRef]

128. Hu, C.; Li, L. Melatonin plays critical role in mesenchymal stem cell-based regenerative medicine in vitro and in vivo. Stem Cell Res. Ther. 2019, 10, 13. [CrossRef]

129. Wang, F.; Zhou, H.; Du, Z.; Chen, X.; Zhu, F.; Wang, Z.; Zhang, Y.; Lin, L.; Qian, M.; Zhang, X.; et al. Cytoprotective effect of melatonin against hypoxia/serum deprivation-induced cell death of bone marrow mesenchymal stem cells in vitro. Eur. J. Pharmacol. 2015, 748, 157-165. [CrossRef]

130. Tang, Y.; Cai, B.; Yuan, F.; He, X.; Lin, X.; Wang, J.; Wang, Y.; Yang, G.Y. Melatonin Pretreatment Improves the Survival and Function of Transplanted Mesenchymal Stem Cells after Focal Cerebral Ischemia. Cell Transpl. 2014, 23, 1279-1291. [CrossRef] [PubMed]

131. Carloni, S.; Albertini, M.C.; Galluzzi, L.; Buonocore, G.; Proietti, F.; Balduini, W. Melatonin reduces endoplasmic reticulum stress and preserves sirtuin 1 expression in neuronal cells of newborn rats after hypoxia-ischemia. J. Pineal Res. 2014, 57, 192-199. [CrossRef]

132. Carloni, S.; Perrone, S.; Buonocore, G.; Longini, M.; Proietti, F.; Balduini, W. Melatonin protects from the long-term consequences of a neonatal hypoxic-ischemic brain injury in rats. J. Pineal Res. 2008, 44, 157-164. [CrossRef] [PubMed] 
133. Carloni, S.; Riparini, G.; Buonocore, G.; Balduini, W. Rapid modulation of the silent information regulator 1 by melatonin after hypoxia-ischemia in the neonatal rat brain. J. Pineal Res. 2017, 63. [CrossRef]

134. Cetinkaya, M.; Alkan, T.; Ozyener, F.; Kafa, I.M.; Kurt, M.A.; Koksal, N. Possible neuroprotective effects of magnesium sulfate and melatonin as both pre- and post-treatment in a neonatal hypoxic-ischemic rat model. Neonatology 2011, 99, 302-310. [CrossRef] [PubMed]

135. Ozyener, F.; Cetinkaya, M.; Alkan, T.; Goren, B.; Kafa, I.M.; Kurt, M.A.; Koksal, N. Neuroprotective effects of melatonin administered alone or in combination with topiramate in neonatal hypoxic-ischemic rat model. Restor. Neurol. Neurosci. 2012, 30, 435-444. [CrossRef]

136. Alonso-Alconada, D.; Alvarez, A.; Lacalle, J.; Hilario, E. Histological study of the protective effect of melatonin on neural cells after neonatal hypoxia-ischemia. Histol. Histopathol. 2012, 27, 771-783. [CrossRef] [PubMed]

137. Hu, Y.; Wang, Z.; Liu, Y.; Pan, S.; Zhang, H.; Fang, M.; Jiang, H.; Yin, J.; Zou, S.; Li, Z.; et al. Melatonin reduces hypoxic-ischaemic (HI) induced autophagy and apoptosis: An in vivo and in vitro investigation in experimental models of neonatal HI brain injury. Neurosci. Lett. 2017, 653, 105-112. [CrossRef] [PubMed]

138. Hu, Y.; Wang, Z.; Pan, S.; Zhang, H.; Fang, M.; Jiang, H.; Zhang, H.; Gao, Z.; Xu, K.; Li, Z.; et al. Melatonin protects against bloodbrain barrier damage by inhibiting the TLR4/ NF-kappaB signaling pathway after LPS treatment in neonatal rats. Oncotarget 2017, 8, 31638-31654. [CrossRef] [PubMed]

139. Xu, L.X.; Lv, Y.; Li, Y.H.; Ding, X.; Wang, Y.; Han, X.; Liu, M.H.; Sun, B.; Feng, X. Melatonin alleviates brain and peripheral tissue edema in a neonatal rat model of hypoxic-ischemic brain damage: The involvement of edema related proteins. BMC Pediatr. 2017, 17, 90. [CrossRef] [PubMed]

140. Sun, Y.; Ma, L.; Jin, M.; Zheng, Y.; Wang, D.; Ni, H. Effects of Melatonin on Neurobehavior and Cognition in a Cerebral Palsy Model of plppr5-/- Mice. Front. Endocrinol. 2021, 12, 598788. [CrossRef] [PubMed]

141. Berger, H.R.; Nyman, A.K.G.; Morken, T.S.; Wideroe, M. Transient effect of melatonin treatment after neonatal hypoxic-ischemic brain injury in rats. PLOS ONE 2019, 14, e0225788. [CrossRef]

142. Yeleswaram, K.; McLaughlin, L.G.; Knipe, J.O.; Schabdach, D. Pharmacokinetics and oral bioavailability of exogenous melatonin in preclinical animal models and clinical implications. J. Pineal Res. 1997, 22, 45-51. [CrossRef] [PubMed]

143. Hornberger, K.; Yu, G.; McKenna, D.; Hubel, A. Cryopreservation of Hematopoietic Stem Cells: Emerging Assays, Cryoprotectant Agents, and Technology to Improve Outcomes. Transfus. Med. Hemother. 2019, 46, 188-196. [CrossRef] [PubMed]

144. Cox, M.A.; Kastrup, J.; Hrubisko, M. Historical perspectives and the future of adverse reactions associated with haemopoietic stem cells cryopreserved with dimethyl sulfoxide. Cell Tissue Bank 2012, 13, 203-215. [CrossRef] [PubMed]

145. Ancuceanu, R.; Dinu, M.; Furtunescu, F.; Boda, D. An inventory of medicinal products causing skin rash: Clinical and regulatory lessons. Exp. Ther. Med. 2019, 18, 5061-5071. [CrossRef] [PubMed]

146. Berger, H.R.; Morken, T.S.; Vettukattil, R.; Brubakk, A.M.; Sonnewald, U.; Wideroe, M. No improvement of neuronal metabolism in the reperfusion phase with melatonin treatment after hypoxic-ischemic brain injury in the neonatal rat. J. Neurochem. 2016, 136, 339-350. [CrossRef]

147. Tann, C.J.; Nakakeeto, M.; Willey, B.A.; Sewegaba, M.; Webb, E.L.; Oke, I.; Mutuuza, E.D.; Peebles, D.; Musoke, M.; Harris, K.A.; et al. Perinatal risk factors for neonatal encephalopathy: An unmatched case-control study. Arch. Dis. Child. Fetal Neonatal Ed. 2018, 103, F250-F256. [CrossRef] [PubMed]

148. Wu, Y.W.; Escobar, G.J.; Grether, J.K.; Croen, L.A.; Greene, J.D.; Newman, T.B. Chorioamnionitis and cerebral palsy in term and near-term infants. JAMA 2003, 290, 2677-2684. [CrossRef]

149. Martinello, K.A.; Meehan, C.; Avdic-Belltheus, A.; Lingam, I.; Ragab, S.; Hristova, M.; Tann, C.J.; Peebles, D.; Hagberg, H.; Wolfs, T.; et al. Acute LPS sensitization and continuous infusion exacerbates hypoxic brain injury in a piglet model of neonatal encephalopathy. Sci. Rep. 2019, 9, 10184. [CrossRef] [PubMed]

150. Falck, M.; Osredkar, D.; Maes, E.; Flatebo, T.; Wood, T.R.; Walloe, L.; Sabir, H.; Thoresen, M. Hypothermia Is Neuroprotective after Severe Hypoxic-Ischaemic Brain Injury in Neonatal Rats Pre-Exposed to PAM3CSK4. Dev. Neurosci. 2018, 40, 189-197. [CrossRef] [PubMed]

151. Osredkar, D.; Thoresen, M.; Maes, E.; Flatebø, T.; Elstad, M.; Sabir, H. Hypothermia is not neuroprotective after infection-sensitized neonatal hypoxic-ischemic brain injury. Resuscitation 2014, 85, 567-572. [CrossRef]

152. Tann, C.J.; Nakakeeto, M.; Hagmann, C.; Webb, E.L.; Nyombi, N.; Namiiro, F.; Harvey-Jones, K.; Muhumuza, A.; Burgoine, K.; Elliott, A.M.; et al. Early cranial ultrasound findings among infants with neonatal encephalopathy in Uganda: An observational study. Pediatr. Res. 2016, 80, 190-196. [CrossRef]

153. Lally, P.J.; Price, D.L.; Pauliah, S.S.; Bainbridge, A.; Kurien, J.; Sivasamy, N.; Cowan, F.M.; Balraj, G.; Ayer, M.; Satheesan, K.; et al. Neonatal encephalopathic cerebral injury in South India assessed by perinatal magnetic resonance biomarkers and early childhood neurodevelopmental outcome. PLoS ONE 2014, 9, e87874. [CrossRef] [PubMed]

154. Fulia, F.; Gitto, E.; Cuzzocrea, S.; Reiter, R.J.; Dugo, L.; Gitto, P.; Barberi, S.; Cordaro, S.; Barberi, I. Increased levels of malondialdehyde and nitrite/nitrate in the blood of asphyxiated newborns: Reduction by melatonin. J. Pineal Res. 2001, 31, 343-349. [CrossRef]

155. Aly, H.; Elmahdy, H.; El-Dib, M.; Rowisha, M.; Awny, M.; El-Gohary, T.; Elbatch, M.; Hamisa, M.; El-Mashad, A.R. Melatonin use for neuroprotection in perinatal asphyxia: A randomized controlled pilot study. J. Perinatol. 2015, 35, 186-191. [CrossRef] [PubMed] 
156. Ahmad, Q.M.; Chishti, A.L.; Waseem, N. Role of melatonin in management of hypoxic ischaemic encephalopathy in newborns: A randomized control trial. J. Pak. Med. Assoc. 2018, 68, 1233-1237.

157. El Farargy, M.S.; Soliman, N.A. A randomized controlled trial on the use of magnesium sulfate and melatonin in neonatal hypoxic ischemic encephalopathy. J. Neonatal Perinatal Med. 2019, 12, 379-384. [CrossRef] [PubMed]

158. Kaye, J.L. Review of paediatric gastrointestinal physiology data relevant to oral drug delivery. Int. J. Clin. Pharm. 2011, 33, 20-24. [CrossRef] [PubMed]

159. DeMuro, R.L.; Nafziger, A.N.; Blask, D.E.; Menhinick, A.M.; Bertino, J.S., Jr. The absolute bioavailability of oral melatonin. J. Clin. Pharmacol. 2000, 40, 781-784. [CrossRef] [PubMed]

160. Carloni, S.; Proietti, F.; Rocchi, M.; Longini, M.; Marseglia, L.; D’Angelo, G.; Balduini, W.; Gitto, E.; Buonocore, G. Melatonin Pharmacokinetics Following Oral Administration in Preterm Neonates. Molecules 2017, 22, 2115. [CrossRef] [PubMed]

161. Ilves, P.; Lintrop, M.; Talvik, I.; Muug, K.; Maipuu, L. Changes in cerebral and visceral blood flow velocities in asphyxiated term neonates with hypoxic-ischemic encephalopathy. J. Ultrasound Med. 2009, 28, 1471-1480. [CrossRef] [PubMed]

162. Hill, C.D.; Jadcherla, S.R. Esophageal mechanosensitive mechanisms are impaired in neonates with hypoxic-ischemic encephalopathy. J. Pediatr. 2013, 162, 976-982. [CrossRef]

163. van den Berg, M.P.; Merkus, P.; Romeijn, S.G.; Verhoef, J.C.; Merkus, F.W. Uptake of melatonin into the cerebrospinal fluid after nasal and intravenous delivery: Studies in rats and comparison with a human study. Pharm. Res. 2004, 21, 799-802. [CrossRef] [PubMed]

164. Jerez-Calero, A.; Salvatierra-Cuenca, M.T.; Benitez-Feliponi, A.; Fernandez-Marin, C.E.; Narbona-Lopez, E.; Uberos-Fernandez, J.; Munoz-Hoyos, A. Hypothermia Plus Melatonin in Asphyctic Newborns: A Randomized-Controlled Pilot Study. Pediatr. Crit. Care Med. 2020, 21, 647-655. [CrossRef] [PubMed] 